\title{
Osmanlı'da Onurlu Bir Diplomat ve Milli Mücadele'nin Önemli Siması: Ahmed Rüstem Bey
}

\begin{abstract}
Dr. Şenol KANTARCI
ÖZET

Makale, Osmanl Devleti döneminde Hariciye Nezareti'nde görev almuş, elçiliklerde çalı̧̧mış, Çetine (Karadağ) ve Washington Büyükelçilikleri yapmış olan Polonya asillı Ahmed Rüstem Bey (Alfred Bielinski) hakkindadır. Rüstem Bey, Washington Büyükelçiliği sırasında Amerikan kamuoyunda Türkiye aleyhine takınılan tutum karşısında Amerikan politikalarına yönelik ă̆ır eleştirilerde bulunarak Türkiye'yi savunmuş ancak bu tutumu yüzünden Amerika Birleşik Devletleri Başkanı Woodrow Wilson tarafindan "İstenmeyen Adam" ilân edilmiş, Osmanlı döneminin sıra dlş̧ bir diplomatıdır. Milli Mücadele döneminde ise Mustafa Kemal Paşa'nın dı̧̧ politika danışmanlığını yapmış ve Mustafa Kemal'in yanında önemli görevlerde bulunmuş olan Ahmed Rüstem Bey, icraatlarindan net bir şekilde anlaşıldlğı üzere Türk milletine sevdal, ömrü boyunca Türk değerlerini savunmuş ve bunun ciddi anlamda mücadelesini vermiş Türk tarihinin önemli şahsiyetlerden birisi olarak inceleme konusu yapılmıştır.
\end{abstract}

Anahtar Kelimeler: Ahmed Rüstem Bey, Alfred Bielinski, Alfred Rüstem Bey, Çetine (Karadağ) Büyükelçisi Ahmed Rüstem Bey, Washington Büyükelçisi Ahmed Rüstem Bey.

An Honorable Ottoman Diplomat Who Was Pronounced "Persona Non Grata" By The Us Government and An Important

Personality of the Turkish Independence Struggle: Ahmed Rüstem Bey (Alfred Bielinski-Alfred Rüstem) ABSTRACT

This article is about a Polish origin Ottoman diplomat Ahmed Rüstem Bey (Alfred Bielinski) who worked at the Ottoman Ministry of Foreign Affairs and its

• Kırıkkale Üniversitesi, İIBF ,Uluslararası İlişkiler Bölümü Öğretim Üyesi. 
several foreign offices such as Çetine (Karadăg) and Washington Embassies. When he was the ambassador in Washington, Rüstem Bey made heavy criticisms of American government which was following a path in opposition to Turkish policies. Because of these criticisms, Ahmed Rüstem Bey, an extraordinary personality and a diplomat, was pronounced "persona non grata" by the US President Woodrow Wilson. He also was an advisor to Mustafa Kemal Pasha on foreign affairs, and he was appointed to important missions during the independence struggle. His attitude and his actions show us that he loved Turkey as much as a Tukish-born Turk can love his country. He defended Turkish values and fought for them throughout his life, and for these attributes he deserves to be a research topic as an important personality in Turkish history.

Key Words: Ahmed Rüstem Bey, Alfred Bielinski, Alfred Rüstem Bey, Ambassador to Çetine (Karadă̆) Ahmed Rüstem Bey, Ambassador to Washington Ahmed Rüstem Bey.

\begin{abstract}
ABD'de iken Beyaz Saray ziyaretinde, yerde serili ay yıldizlı hallyl görünce sinirlenen Ahmed Rüstem Bey: "Bu yere serdiğiniz ve çiğnenmesini istediğiniz hall, benim ülkemin onurudur. Üzerinde dini inancımızın, hem de bayrağımızın ay yıldızı var. Onun yeri ayakların altı değil, ellerin erişemeyeceği yükseklerdedir. Bu hal buradan kaldırılana kadar sarayınıza adım atmam mümkün olmayacaktır." demiştir.
\end{abstract}

$\mathrm{Bu}$ makalede inceleme konusu yapılan Leh asılll Ahmed Rüstem Bey, (Alfred Bielinski) Osmanlı Devleti döneminde Hariciye Nezareti'nde görev almış, elçiliklerde çalışmış, 1897'de Osmanlı-Yunan Harbi'ne Tesalya Ordusu'nda Yunanlılara karşı kazanılan Dömeke Muharebesi'nde fahri yüzbaşı rütbesi ile savaşmış ve savaş sonrasında Osmanlı Devleti tarafindan 'Yunan Muhârebe Madalyası' ile ödüllendirilmiş, Çetine (Karadağ) ve Washington Büyükelçilikleri yapmış, Washington Büyükelçiliği sırasında Amerikan kamuoyunda Türkiye aleyhine takınılan tutum karşısında Amerikan politikalarına yönelik ağır eleştirilerde bulunarak Türkiye'yi savunmuş ancak bu tutumu yüzünden Amerika Birleşik Devletleri (ABD) Başkanı Woodrow Wilson tarafından "İstenmeyen Adam" ilân edilmiş olan Osmanlı döneminin sıra dışı bir diplomatıdır.

Washington Büyükelçiliği görevinden sonra İstanbul'a dönen Ahmed Rüstem Bey, işgaller döneminde İstanbul'dan Anadolu'ya Mustafa Kemal Paşa'nın yanına gitmiş, Sivas'ta Mustafa Kemal Paşa tarafından önce 'Hey'eti Temsiliye İstişare Kurulu Üyesi' yapılmış, daha sonra Ankara Mebusu olarak son Osmanlı Meclis-i Mebusanı'nda görev almıştır. Meclis-i 
Mebusan'ın dağılması üzerine İstanbul'dan Ankara'ya gelen Ahmed Rüstem Bey, Birinci Büyük Millet Meclisi'ne Ankara Milletvekili olarak katılmış, daha sonra ise, 24 Mayıs 1920 günlü Padişah buyruğu ile Mustafa Kemal Paşa ile birlikte idama mahkûm edilmiştir.

İcraatlarından net bir şekilde anlaşıldığı üzere Türk milletine sevdalı, ömrü boyunca Türk değerlerini savunmuş ve bunun ciddi anlamda mücadelesini vermiş Türk tarihinin önemli şahsiyetlerden birisidir.

Beyaz Saray ziyaretinde, yerde serili ay yıldızlı halıyı görünce sinirlenen Ahmed Rüstem Bey: "Bu yere serdiğiniz ve çiğnenmesini istediğiniz hall, benim ülkemin onurudur. Üzerinde dini inancımızın, hem de bayrağımızın ay yıldızı var. Onun yeri ayakların altı değil, ellerin erişemeyeceği yükseklerdedir. Bu halı buradan kaldırılana kadar sarayınıza adım atmam mümkün olmayacaktır." șeklindeki bu ve diğer olaylarda, daha birçok sözlü ve fiili eylemi, Rüstem Bey'in Türkiye'ye, Türk milletine olan bağlılığını göstermesi bakımından dikkate şayandır.

Ahmed Rüstem Bey, kişilik olarak heyecanl1, mücadeleci, asabi yaradılışlı, adil, haksızlığa tahammülü olmayan ve anlaşıldığı kadarıyla biraz fazlaca hassas/kırılgan bir ruha sahiptir. Kişiliğine ait bu yönleri de makale içerisinde aydınlatılmıştır.

İncelemede Ahmed Rüstem Bey ile ilgili bu güne kadar yayımlanmış olan çalıșmalarda bir kısım eksik, hatta yanlış bilgilerin olduğu tespit edilmiş ve kendisi ile ilgili daha önce görülmediği anlaşılan arşiv vesikaları ışı̆̆ında (Başbakanlık Osmanlı Arşivi, Başbakanlık Cumhuriyet Arşivi, Dışişleri Bakanlığ 1 Arşivi, Cumhurbaşkanlığ Arşivi) Ahmed Rüstem Bey portresi, bütün yönleriyle, daha önce yayımlanmış olan bilgiler de göz önünde bulundurularak yeniden ortaya konulmuştur.

\section{Ahmed Rüstem Bey}

Ahmed Rüstem Bey'in babası, 1848'de Macaristan'da Avusturya'ya karşı başarısızlıkla sonuçlanmış olan ayaklanma ve devrimin ardından Osmanlı Devleti'ne sığınarak, devletin hizmetine giren² Polonyalı Seweryn Bielinski'dir. Seweryn Bielinski, Osmanlı tabiiyetine geçtikten sonra 'Nihâd' ismini almıştır. Bulgaristan Komiserliği yapan Rüstem Bey'in babası Nihâd Paşa'nın ${ }^{3}$ ismi, şu ana kadar yazılmış olan kaynaklarda

\footnotetext{
${ }^{1}$ Sabah Gazetesi, 3 Ekim 1999.

${ }^{2}$ Ahmed Rüstem Bey, Cihan Harbi ve Türk-Ermeni Meselesi (Orijinal Adı: La Guerre Mondıale La Question Turco-Arménıenne (1918)), Çev. Cengiz Aydın, İstanbul, 2001, s.11.

${ }^{3}$ BOA, Y.PRK.HR.,Dosya No: 32, Gömlek No: 79,1320.Z.25.
} 
Sadettin Nihat Paşa $a^{4}$, Saadettin Nihat Paşa ${ }^{5}$, Sadrettin Nihat Paşa $a^{6}$ şeklinde yazılmış olsa da bunun böyle olmadığı, ismin sadece (Sadettin veya Sadrettin ön adı olmadan) 'Nihâd' olduğu, bu zatla ilgili arşiv vesikalarında (sicil dosyasında) görülmüştür. Zira bu yanlışlığın, Bâb-l Âlî Nezâret-i Umûr-ı Hâriciyye Sicill-i Ahvâl Müdîriyyeti'nde bulunan Rüstem Bey'in sicilinde babasının ismi verilirken yazılı olan "saadetlu" kelimesinin "Sadettin-Sadrettin" şeklinde yanlış olarak okunmasından kaynaklandığı ve bu yanlışın da bundan sonra yazılan diğer bütün kaynaklarda devam ettirildiği tespit edilmiştir. Bu iddiayı destekleyen unsurlardan birisi de arşiv belgelerinde Rüstem Bey'in Bulgaristan Komiserliği yapan babası ile ilgili bütün belgelerde ismin sadece "Nihâd Paşa" olarak geçmesinin yanı sıra Başbakanlık Osmanlı Arşivleri'nde bulunan Seweryn Bielinski (Nihâd Paşa)'ye ait sicil dosyasında da ismin "Nihâd" olarak geçmesidir. Asıl ismi Seweryn Bielinski olan Nihâd Paşa, Osmanlı Devleti tabiiyetine geçtikten sonra birçok önemli görevde bulunmuştur.

Alfred Bielinski, 18 Nisan 1862 yılında Midilli’de doğmuştur. ${ }^{8}$ Babası Polonyalı annesi İngiliz'dir. 1854 yılında (1270 Zilkadesinde) babas1 Seweryn Bielinski'nin Osmanlı Devleti hizmetine geçtiği bilinmektedir. ${ }^{9}$ Resmi belgelerde ${ }^{10}$ 'Alfred' isminin yazilı olmas1, Alfred Bielinski'nin uzunca bir süre bu isimle kaldığ 1 ancak daha sonra kendi isteği ile Müslümanlığı seçtiği ve 'Ahmed Rüstem' adını aldığı anlaşılmaktadır.

${ }^{4}$ Hikmet Denizli, Sivas Kongresi Delegeleri ve Heyet-i Temsiliye Üyeleri, Ankara, 1996, s.89.

${ }^{5}$ Mine Erol, Osmanlı İmparatorluğu'nun Amerika Büyükelçisi Rüstem Bey, Ankara, 1973, s.7; İnönü Ansiklopedisi, C. 1., Ankara, 1946, s. 269.

${ }^{6}$ Büyük Larousse Sözlük ve Ansiklopedisi, C. 1., s.218

7 BOA, Y.A.HUS., Dosya No: 164, Gömlek No: 29, 27.4.1297; BOA, Y.A.HUS., Dosya No: 170, Gömlek No: 30, 28.6.1299; BOA, Y.A.HUS., Dosya No: 173, Gömlek No: 45, 6.6.1300; BOA, Y.A.HUS., Dosya No: 175, Gömlek No: 1, 2.1.1301; BOA, Y.A.HUS., Dosya No: 183, Gömlek No: 17, 9.12.1302.

${ }^{8}$ BOA, Y.PRK.HR.,Dosya No: 32, Gömlek No: 79,1320.Z.25. (Ahmed Rüstem Bey'in sicilinde doğum tarihi 'Binikiyüzaltmışüç senesi Cumâde'l-ûlâsının ikisinde Midilli ceziresinde tevellüd etmiştir' şeklinde yazılmıştır. Ancak bunun doğru olmadığ anlaşılmaktadır. Zira, Alfred Rüstem'in babası Nihâd Paşa'nın sicil dosyası incelendiğinde Rüstem Bey'in Midilli'de 1862'de doğmuş olduğu kanaati güçlenmektedir.) BOA, Y.PRK.HR.,Dosya No: 32, Gömlek No: 79,1320.Z.25.

${ }^{9}$ Erol, ... Rüstem Bey, s.7.

${ }^{10}$ BOA, İRADE, Dosya No: Mabeyn, Gömlek No: 22, 22.C.1332; BOA, İRADE, Dosya No: Mabeyn, Gömlek No: 26, 25.C.1332; BOA, Meclis-i Vükela Mazbatası, Dosya No: 207, Gömlek No: 29, 1335.Ca.20. Bazı belgelerde ise, "Alfred Bey" olarak geçmektedir: BOA, Y.A.HUS, Dosya No: 263, Gömlek No: 97, 25.1.1310; BOA, Y.A.RES, Dosya No: 110, Gömlek No: 62, 1318.9.12; BOA, Y.PRK.A, Dosya No: 7, Gömlek No: 91, 1310.M.24. Roma Sefareti Katipliğine tayini ile ilgili bir belgede de doğrudan "Alfred Bielinski "ismi kullanıldığ1 görülmüştür: BOA, Y.PRK.EŞA, Dosya No: 17, Gömlek No: 61, 1310.Za.13. 
Ahmed Rüstem, İlkokulu İzmir'de İngiliz Mektebi'nde okuduktan sonra liseyi İstanbul Kadıköy'de Frer Mektebi'nde tamamlamış daha sonra Avusturya'da Lümberg şehrinde yüksek tahsilini yaparak diplomasını almış ve İstanbul'a dönmüștür. ${ }^{11}$

Ahmed Rüstem Bey, İstanbul'a döndükten sonra bir süreliğine de Galatasaray Lisesi'nde derslere girmiştir. Fransızca, İngilizce, Almanca, Lehçe, Rumca, İtalyanca, Arapça ve Farsça gibi dillere vakıf olan Ahmed Rüstem Bey, 1881 y1lında Bulgaristan Komiserliği fahri Fransızca Kâtibi olarak binbeşyüz kuruş maaşla Hariciye Nezareti'nde göreve başlamıştır ${ }^{12}$.

Ahmed Rüstem Bey, Aralık 1885'te Bulgaristan Sefareti Fransizca Kâtipliği'nden azledilmiş ve daha sonra 1 Haziran 1886 'da Atina Sefareti Üçüncü Kâtipliği'ne tayin olmuştur. ${ }^{13}$ Dört yıl Atina Sefareti'nde çalıştıktan sonra 3 Haziran 1890'da Belgrad Sefareti'nde aynı göreve getirilen Ahmed Rüstem Bey yaklaşık üç ay sonra 2 Eylül 1890'da istifa ederek bu görevinden ayrılmıştır. ${ }^{14} \mathrm{Bu}$ defa 13 Kasım 1890 'da aynı sefaretin ikinci kâtipliğine ataması yapılmıştır. İki ay sonra da (22 Ocak 1891'de) Atina Sefareti İkinci Kâtipliği'ne tayin olmuştur. Yaklaşık iki yıl, Atina Sefareti'nde çalıştıktan sonra, ${ }^{15} 7$ Mayıs 1893 yılında Londra Sefareti İkinci Kâtipliği'ne atanmıştır. ${ }^{16}$ Rüstem Bey, Londra'daki bu görevinden sonra, terfi etmiş ve 14 Ocak 1894 yılında Bükreş Sefareti Başkâtipliği görevine getirilmiştir. ${ }^{17} 13$ Nisan 1897 'de Washington Sefareti Başkâtipliği'ne atanan Ahmed Rüstem Bey, 1897'de Osmanl1-Yunan harbine gönüllü olarak katılmıştır. Teselya Ordusu'nda Dömeke Muharebesi'ne fahri yüzbaşı olarak katılmış olan Rüstem Bey, bu hizmetinden dolayı 4 Eylül 1897'de Osmanlı

${ }^{11}$ BOA, Y.PRK.HR.,Dosya No: 32, Gömlek No: 79,1320.Z.25; Dışişleri Bakanlığı Arşivi (Tasnif edilmemiş).

${ }^{12}$ BOA, Y.PRK.HR.,Dosya No: 32, Gömlek No: 79,1320.Z.25; Dışişleri Bakanlığı Arşivi (Tasnif edilmemiş).

${ }^{13}$ BOA, İ.MTZ (04), Dosya No: 28, Gömlek No: 1805, 1303. S.25; BOA, İ. HR, Dosya No: 302, Gömlek No: 19140, 1303.S.25; Dışişleri Bakanlığı Arşivi (Tasnif edilmemiş).

${ }^{14}$ BOA, Y.PRK.HR.,Dosya No: 32, Gömlek No: 79,1320.Z.25; Dışişleri Bakanlığı Arşivi (Tasnif edilmemiş).

15 BOA, Y.PRK.HR.,Dosya No: 32, Gömlek No: 79,1320.Z.25; Dışişleri Bakanlığı Arşivi (Tasnif edilmemiş).

${ }^{16}$ BOA, Y.PRK.EŞA.,Dosya No:17, Gömlek No:61, 1310.Za.13. Hariciye Nezareti tarafından 29 Mayıs 1893 'te gönderilen tahrirat ile Londra Büyükelçisi Rüstem Paşa'dan Londra Sefareti katipliğine tayin olunan Alfred Bey'e gerekli kolaylığın gösterilmesi konusunda ricada bulunulmuştur. (BOA, Y.PRK.EŞA.,Dosya No:17, Gömlek No:61, 1310.Za.13.).

${ }^{17}$ BOA, Y.PRK.HR.,Dosya No: 32, Gömlek No: 79,1320.Z.25; Dışişleri Bakanlığı Arşivi (Tasnif edilmemiş). 
Devleti tarafından "Yunan Muhârebe Madalyası" ile ödüllendirilmiștir. ${ }^{18}$ Rüstem Bey, 1909 yılında Hariciye Nezareti'ne vermiş olduğu dilekçe ile Fahri Yüzbaşıllk rütbesini siciline işlettirmiştir. ${ }^{19}$

Eylül 1897'de Bükreş Sefareti Başkâtibi olan Rüstem Bey'e bu görevi sirasında Romanya hükümeti, üçüncü rütbeden Kron dö Romani nişânı vermiştir. $^{20}$ Rüstem Bey, 10 Temmuz $1898^{\prime}$ de Londra Sefareti Başkâtipliği'ne getirildikten kısa bir süre sonra 11 Ocak 1899'da yeniden Washington Sefareti Başkâtipliği'ne ataması yapılmıştır. ${ }^{21}$

Osmanlı'da Stradışı Bir Diplomat: Rüstem Bey'in Osmanlı Hariciyesi'ni Kızdıran Giriş̧imi

Ahmed Rüstem Bey'in Washington Sefareti Başkâtipliği görevi sırasında Hariciye Nezareti'ni yakından ilgilendirecek olan bir girişimi vuku bulmuştur. Washington'da bulunduğu sırada Büyükelçilik mensuplarının aylıklarını alamadıklarını ve kötü durumda olduklarını bu yüzden de çeşitli yolsuzluklar yaptığını görmüş ve Londra'da çıkan "Daily Mail" adlı gazetede bu durumu ve yolsuzlukları anlatan bir makale yazmıştır. ${ }^{22}$ Gazetede çıkan yazının muhtevasını öğrenen Osmanlı Hariciye Nezareti, doğal olarak bu durumdan rahatsız olmuştur. Yazının yayınından sonra arşiv belgelerinden anlaşıldığına göre kendi isteğiyle Amerika'dan ayrılan Rüstem Bey, Londra'ya gitmiştir. Hariciye Nazırı Tevfik Paşa, Rüstem Bey'in Londra'da olup olmadığını öğrenmek maksadı ile 22 Şubat 1900'de Londra'daki Osmanlı Büyükelçisi Kostaki Antopulo'ya çektiği telgrafla Rüstem Bey'in Londra'da olduğunu öğrenmiştir. Hariciye Nazırı Tevfik Paşa, 27 Şubat'ta Osmanlı Büyükelçisi Kostaki Antopulo'ya yeniden telgraf çekerek Ahmed Rüstem Bey'in yeni bir vazife ile görevlendirileceğinden İstanbul'a gönderilmesini istemiştir. Aslında Rüstem Bey'in İstanbul'a çağrılmasının sebebi "Daily Mail" gazetesinde yazmış olduğu Hariciye mensuplarının durumunu anlatan makalesidir. ${ }^{23}$ Makalenin yayınlanmasından sonra Osmanlı İngiltere Sefiri'nin, Ahmed Rüstem Bey'in bu görevinden alınmasını ve bir daha Amerika'ya avdetine müsaade

${ }^{18}$ BOA, İ. TAL, Dosya No: 120, Gömlek No: 1315/R-263, 1315.R.4;

${ }^{19}$ BOA, İ.TAL, Dosya No: 461, Gömlek No: 1327/C-04, 1327.C.8. Dişişleri Bakanlığı Arşivi (Tasnif edilmemiş).

${ }^{20}$ BOA, İ. TAL, Dosya No: 119, Gömlek No: 1315/R-74, 1315.R.4; BOA, İ. HR, Dosya No: 361, Gömlek No: 1316/Ş-18, 1316.Ş.28.

${ }^{21}$ BOA, Y.PRK.HR.,Dosya No: 32, Gömlek No: 79,1320.Z.25; BOA, İ.HUS, Dosya No: 54, Gömlek No: 1315.M/72, 1315.M.30.

${ }^{22}$ BOA, Y.PRK. HR, Dosya No: 32, Gömlek No: 77, 1320.Z.25.

${ }^{23}$ BOA, Y.PRK.HR.,Dosya No: 32, Gömlek No: 77,1320.Z.25. 
edilmemesi istediğini Washington Sefiri'nden istemiş ve sefir de bu durumu Hariciye Nezareti'ne bildirmiştir. ${ }^{24}$

Daily Mail adlı gazetedeki makalenin kendisine ait olup olmadığı Londra Büyükelçiliği tarafından kendisine sorulan Ahmed Rüstem Bey, makalenin kendisine ait olduğunu bir mektup ile 2 Ekim 1900'de Osmanlı'nın Londra Büyükelçisi Kostaki Antopulo'ya bildirmiştir. Mektubunda makaleyi kaleme almasının sebeplerini izah eden Ahmed Rüstem Bey, Osmanlı diplomatlarının davranışlarının Osmanlı adını kirlettiğini, İstanbul, maddi sıkıntılar içerisinde iken Hariciye paralarının lüzumlu yerlere harcanmayışının doğru olmadığını hatta bazı Hariciyecilerin bu şekilde zengin olduklarını anlattıktan sonra söz konusu makaleyi yazdığına pişman olmadığını, iyi niyetle hareket ettiğini ve bunun Osmanlı halkına karşı bir vazife olduğuna işaret etmiştir. Mektubunun sonunda, bu hareketinden dolayı da suçlu olamayacağını dolayısıyla istifa etmeyeceğini belirtmiş ve eğer Hariciye Nezareti isterse kendisini görevden alabileceklerini yazmıştır. Osmanlı Devleti'nin Londra Büyükelçisi Kostaki Antopulo'ya göndermiş olduğu bu mektubun, hükümete gönderilmesini ve İstanbul'da bir gazetede neşredilmesini isteyen Rüstem Bey, eğer mektup İstanbul'a gönderilmez ve neşredilmez ise mektubu, Londra gazetelerinde neşredeceği tehdidini yapmıştır. ${ }^{25}$

Büyükelçi Kostaki Antopulo mektubu aldıktan sonra Rüstem Bey'in isteği doğrultusunda kendi telgrafi ile beraber Rüstem Bey'in mektubunu 3 Ekim 1900 tarihinde İstanbul'a göndermiștir. ${ }^{26}$

Hariciye Nazırı Tevfik Paşa, 20 Ekim'de bir telgrafla yeniden Londra Büyükelçiliği'ne Rüstem Bey'in İstanbul'a gelmesi hususunda yola çıkıp çıkmadığını sormuş ancak 23 Ekim tarihli verilen cevapta Ahmed Rüstem Bey'in hala Londra'da olduğu bildirilmiştir. ${ }^{27}$

The New York Times'ın Londra çıkışlı 24 Nisan 1901 tarihli haberinde Rüstem Bey'in Osmanlı Hariciyesi tarafından ihanetle suçlandığı yazılmış ve Rüstem Bey'in konu hakkındaki kendisini haklı gören görüşüne yer verilmiştir. $^{28}$

Arşiv belgelerinden anlaşıldığına göre, Londra'da bir süre işsiz kalan Ahmed Rüstem Bey’in 1903 yılında Londra'dan ayrilarak gemiyle Malta

\footnotetext{
${ }^{24}$ BOA, Y.PRK.EŞA, Dosya No: 33, Gömlek No: 96, 1317.Ca.17.

25 Erol, ...Rüstem Bey, s.10; BOA, Y.PRK.HR.,Dosya No: 32, Gömlek No: 77,1320.Z.25.

${ }^{26}$ Erol, ....Rüstem Bey, s.10.

${ }^{27}$ Erol, ... Rüstem Bey, s.8-9-10.

${ }^{28}$ The New York Times, 24 Nisan 1901.
} 
adasına geldiği ve buradan da kendisine iş bulmak niyetiyle yine vapurla İskenderiye'ye gideceği ve eğer orada da iş bulamaz ise, Siyam'a gideceği bilgisi, Londra Sefareti tarafından Hariciye Nezareti'ne bildirilmiştir. ${ }^{29}$

Ahmed Rüstem Bey, Malta'da dört gün teyzesinin kocas1 olan İngiltere'nin eski Selanik Konsolosu John Blunt'in evinde misafir olmuştur. 3 Mart 1903'te vapurla geldiği Malta'da Ahmed Rüstem Bey'in kaldığ süre içerisinde nerede konakladığ1, ne yaptığ1, kimlerle görüştüğü Malta Başşehbenderi tarafından rapor edilmiştir. ${ }^{30}$ Londra Büyükelçiliği de Hariciye Nezareti'ne 10 Mart 1903 tarihinde konu ile ilgili bilgi vermiştir. ${ }^{31}$ Rüstem Bey'in İskenderiye'ye gitmek üzere Malta'dan ayrılmış olduğu bilgisi dahi ihmal edilmeden bildirilmiştir. ${ }^{32}$ Vesikalardan anlaşıldığına göre bu dönemde Ahmed Rüstem Bey sıkı takibat altında tutulmuştur. ${ }^{33}$

1903 yılından Washington'a Maslahatgüzar olarak atandığ 25 Ağustos 1909 yılına kadar yaklaşık 6 yıl süreyle Hariciye mesleğinden uzak kalan Ahmed Rüstem Bey, bu süre içerisinde Mısır'da (Kahire'de) gazetecilik yaparak geçimini idame ettirmiştir. ${ }^{34}$

\section{Hariciye Nezareti Tarafindan Rüstem Bey'e Verilen İlgi Çekici Görev}

Rüstem Bey, 25 Ağustos 1909 yllında atandığ 1 Washington Maslahatgüzarlığ 1 görevini de fazla devam ettirememiştir. Yaklaşık olarak 8,5 ay sonra, 16 Mayıs 1910 yılında İstanbul'a çağrılmış ve kendisi açısından oldukça ilginç sayılabilecek bir görev verilmiştir. Rüstem Bey'e verilen görev, Hariciye'de yeni vuku bulmuş bir yolsuzluk olayının soruşturmacılığını yapmasıdır. Paris Osmanlı elçisi Naum Paşa, Hariciye Nezareti'ne yazdığı 27 Eylül 1910 tarihli mektubunda Sefaret Konseyi'nin bu görevi Rüstem Bey'e verdiğini bildirmiştir. Paris Başkonsolosu Lütfi Bey ile ilgili olan bu yolsuzluk soruşturmasında Rüstem Bey, konuyla ilgili geniş bir rapor hazırlamıştır. Hazırladığı raporunda, Paris Başkonsolosu Lütfi Bey'in Konsolosluğu sırasında bazı mühim evrakları çaldığını ve bir takım suiistimaller yaparak devletten haksız kazanç elde ettiğini ve ceza gerektiren hareketlerde bulunduğunu yazmıştır. Naum Paşa, Rüstem Bey'in soruşturma raporunu Hariciye Nazırı Rıfat Paşa'ya göndermiş ve Ahmed Rüstem Bey'den önce konu ile ilgili tahkikat yapan İstanbulian Efendiden haberi

${ }^{29}$ BOA, Y.PRK.HR.,Dosya No: 32, Gömlek No: 74,1320.Z.25.

30 Erol, ...Rüstem Bey, s. 12. (BOA, Y.PRK.HR.,Dosya No: 32, Gömlek No: 76,1320.Z.25.).

${ }^{31}$ BOA, Y.PRK.HR.,Dosya No: 32, Gömlek No: 74,1320.Z.25.

${ }^{32}$ BOA, Y.PRK.HR, Dosya No: 32, Gömlek No: 76, 1310.Z.12.

${ }_{33}^{3}$ BOA, Y.PRK.HR.,Dosya No: 32, Gömlek No: 69,1320.Z.25.

${ }^{34}$ Büyük Larousse, C. 1., s.218. 
olmadığını, ondan da, İstanbul'da olduğuna göre konu ile ilgili bilgi alınabileceğini ancak asıl neticenin Rüstem Bey'in raporundan çıkartılabileceğini bildirmiştir. ${ }^{35}$

$\mathrm{Bu}$ görevin Rüstem Bey'e verilmesi hatta Naum Paşa'nın Hariciye Nazırı'ndan Rüstem Bey'in soruşturma raporunu esas alarak kararını vermesini istemesi, bir taraftan Ahmed Rüstem Bey için bir anlamda iade-i itibar olduğu gibi diğer taraftan da Rüstem Bey'in Hariciye çevresinde bırakmış olduğu adil ve dürüst kişiliğini göstermesi bakımından önemlidir. ${ }^{36}$

Paris Başkonsolosu Lütfi Bey'in soruşturması görevinden sonra Rüstem Bey 1911 yılında Büyükelçi sıfatıyla Çetine'ye (Karadağ'a) tayin olmuştur. ${ }^{37}$ Ahmed Rüstem Bey'in bu görevini 1912 yılında da sürdürdüğü Çetine'den İstanbul'a gönderdiği raporlarından anlaşılmaktadır. ${ }^{38} 1912$ yılında başlayan Balkan Harbi sırasında İstanbul'a çağrılan Ahmed Rüstem Bey, harbin sonunda büyükelçi olarak bu defa Amerika Birleşik Devletleri'ne gitmiştir.

\section{Ahmed Rüstem Bey'in Washington Büyükelçiliği ve Amerikan Yönetimi Tarafindan "İstenmeyen Adam" İlân Edilişi}

18 Mayıs 1914'te ${ }^{39}$ Washington'a büyükelçi olarak Osmanlı Devleti tarafindan atanan Ahmed Rüstem Bey, aslında Amerikan Hariciyesi için yeni bir şahsiyet değildir. Kendisi daha önce Washington'da ikinci kâtip, maslahatgüzar ve konsolos olarak muhtelif tarihlerde görevde bulunmuştur. Bu yüzden Amerikan yönetimi tarafından Rüstem Bey’in büyükelçi olarak atanmasında herhangi bir diplomatik sıkıntı yaşanmamıştır. ${ }^{40}$ Rüstem Bey'in Washington'da göreve başladığı dönemde ABD Başkanı, Woodrow Wilson'dir.

Rüstem Bey'in Washington Büyükelçiliği görevine başladığı dönem Osmanlı Devleti için, Balkan Harbi'nin hemen sonrasında yeni ve büyük bir savaşın başlangıcı olduğu gibi, imparatorluğun da son yıllarını yaşadığı s1kıntılı bir süreçtir.

1878 Berlin Kongresi'nden sonra Osmanlı Devleti içerisinde siyasallaşmaya başlayan Ermeniler, bir taraftan Osmanlı Devleti içerisinde

\footnotetext{
${ }^{35}$ Erol, ... Rüstem Bey, s. 13-14.

${ }^{36}$ Erol, .... Rüstem Bey, s.14.

${ }^{37}$ BOA, İ.HR, Dosya No: 427, Gömlek No: 1329/Z-06, 1329.Z.21; Erol, ...Rüstem Bey, s.14-15.

${ }^{38}$ BOA, HR.SYS, Dosya No:150, Gömlek No: 2210, 1912.1.30.

${ }^{39}$ BOA, İ.MBH, Dosya No: 15, Gömlek No: 1332/C-022, 1332.C.22; BOA, İ.MBH, Dosya No: 15, Gömlek No:1332/C-26, 1332.C.25. (Ziya Paşa görevden alınarak yerine Rüstem Bey 'Washington Büyükelçisi' olarak tayin edilmiştir.).

${ }^{40}$ Erol, ...Rüstem Bey, s. 16-17.
} 
isyan ve tedhiş hareketlerinde bulunurken diğer taraftan da çeşitli Batı ülkelerinde Osmanlı Devleti aleyhine yoğun bir şekilde karalama kampanyaları düzenlemekteydiler.

Ermenilerin Osmanlı Devleti aleyhine karalama kampanyas1 düzenledikleri yerlerin başında ise ABD gelmekteydi. ${ }^{41}$ ABD'de Rumlarla birlikte hareket eden Ermeniler, Amerikan kamuoyunda Türkiye aleyhine çalışmalar yürütürken Amerikan yönetimi, bu duruma seyirci kalmıştır. Bu dönemde ABD'deki gazetelerde Türkler ve Osmanlı Devleti ile ilgili çıkan yazılarda, Türkler ve Osmanlı Devleti aleyhine hakarete varan sözler sarf edilirken, masum Ermenilerin barbar Türkler tarafından katledildiği yalanları Amerikan gazetelerinde yer alıyordu. Washington'da büyükelçilik görevi sırasında karşı karşıya kaldığı bu durum Rüstem Bey'i sarsmıştır. Daha önce Balkan Harbi'nden Osmanlı Devleti'nin yenik çıkması üzerine, Amerikan gazeteleri, Osmanlı Devleti ile alay etmişlerdi. ${ }^{42}$ Rüstem Bey, ABD'deki büyükelçiliği döneminin daha başlarında ciddi sorunlarla baş başa kalmıştı. Bunlardan ilki Osmanlı yönetiminin İngiltere'ye parasını ödeyerek satın aldığ 1 halde 'Sultan Osman' ve 'Reşadiye' adlı iki savaş gemisinin Türkiye'ye teslim edilmemesinin yanı sıra ABD'nin 'Idaho' ve 'Missisipi' adlarındaki iki zırhlıyı Yunanistan'a satma kararıydı. Rüstem Bey, Türkiye ile Yunanistan arasındaki güç dengesini etkileyecek olan bu zırhlıların Yunanistan'a satışını engellemek maksadı ile ABD Başkanı Wilson ile görüşmüşse de bir netice alamamıştır. ABD Senato'sunun kararı ile bu savaş gemileri Yunanistan'a satılmıştır. Rüstem Bey, durumu Sadrazam Said Halim Paşa'ya bildirmiş, Yunanlıların 20 yıldan beri ABD'de Türkiye aleyhtarı propaganda faaliyetleri yürüttükleri ve buna karşı da propaganda ile cevap vermek gerektiği, bunun için de kendisinin devamlı surette gazetelere demeçler verdiğini ve makaleler yazarak yayımlattığını bildirmiştir. ${ }^{43}$

Rüstem Bey'in büyükelçiliğinin daha başlarında karşılaştığı sorunlardan birisi de Ermeni konusuydu. ABD'de Birinci Dünya Savaşı sırasında da Ermenilerin kullanılarak Osmanlı üzerine yoğun karalama kampanyası yürütüldüğünü gören Ahmed Rüstem Bey, diplomatik kaideleri bir tarafa

41 Şenol Kantarcı, Amerika Birleşik Devletleri'nde Ermeniler ve Ermeni Lobisi, İstanbul, 2004.

${ }^{42}$ Erol, ....Rüstem Bey, s. 18-21

${ }^{43}$ Süleyman Beyoğlu, "Milli Mücadelenin Az Bilinen Bir Siması: Ahmet Rüstem Bey (Alfred Bilinski 1862-1935), VI. Uluslararası Atatürk Kongresi (Kasım -2007). Bu makaleyi yayına hazırladığım sırada değerli hocam Prof. Dr. Süleyman Beyoğlu bilim adamı sorumluluğuyla büyük bir incelik göstererek Kongre'de sunuş olduğu ve henüz yayımlanmamış olan tebliğini bana göndermiştir. Sayın Prof. Dr. Beyoğlu'nun bu duyarlılığının dikkate şayan olduğunu ifade ederek kendisine teşekkür ediyorum. (Tebliğ yayınlanmadığından sayfa numarası verilmemiştir.) 
birakarak bu hareketleri protesto amaciyla 8 Eylül 1914'te 'Evening Star' gazetesine zehir zemberek bir beyanat vermiştir. ${ }^{44}$

Beyanatında Rüstem Bey, İngiltere ve Fransa'nın Türkiye'ye karşı kamuoyu oluşturarak ABD'yi tahrik ettiklerini, Türk limanlarına Amerikan savaş gemileri göndermesini ABD'den talep etmek bahanesiyle gerçeklere tam ehemmiyet vermeyerek geleceğin korkunç bir resmini yaptıklarını belirttikten sonra, yüzyıllardır Osmanlı vatandaşı olarak barış ve huzur içerisinde yaşayan Ermenilerin İngiltere, Rusya ve Fransa gibi devletlerce desteklenerek isyanlar çıkardıklarını ve savaş sırasında Osmanlı Devleti'ni zayıflatmak için Ermenilerin Osmanlı Devleti'nin savaştığı ülkelerle işbirliği içerisine girdiklerini, dolayısıyla bu konuda Osmanlı yönetiminin haklı olduğunu belirttikten sonra beyanatına şöyle devam etmiştir: “...masum bir ırka karşı dünya'nın gözü önüne sadece bir değil 20 program seren Rusya; memleketin özgürlüğ̈̈ için dövüşen Cezayirlileri mağaralara doldurup dumanla öldüren, sonra da büyük eserleri 'Commune' yüzünden sevinç duyan Fransa; (Hint isyanındaki asileri) cezalandırmak için hepsini kurşunlayan İngiltere, aynı tahrikler karşısında olsaydı ne yapardı?"

Ahmed Rüstem Bey beyanatında ABD'ye de ağır eleştirilerde bulunmuştur. Rüstem Bey ABD ile ilgili olarak da şunları söylemiştir:

"Birçok gazetelerin bu işte İngiltere ve Fransa'nın tarafinı tutmasından beri, kendimi, şunu söylemeğe yetkili buluyorum ki, Amerika Birleşik Devletleri'nde her gün vuku bulan linçleme düşüncesi ve Filipinlerdeki Wate Cure denilen işkence hatıraları Türkiye'ye hücumda onu itiyatl yapmalı idi. Çünkü Italya'nın iktisadi rekabeti veyahut Filipinler'in katledilmesi ve hatta zencilerin tecavüzü ile mukayese edilirse, onun tahrik neticesinde yaptı̆̆ vahşilik hiç kalır. Hakikatte hiç vuku bulmayan bir şeyi sadece münakaşanın hatırı için olduğunu farz edelim. Zencilerin, Amerika Birleşik Devletleri'nin istilasını kolaylaştırmak için Japonlarla gizli anlaşmalarla birleştiği keşfolunsa, onlardan kaç tanesi bu hikâyeyi anlatmak için hayatta birakılacaktı?..."46

Ahmed Rüstem Bey, verdiği beyanatında, asırlar boyunca Osmanlı Devleti'nde yaşamlarını özgürce sürdüren Ermenilerin, Osmanlı'ya ihanet ettiklerini, Rusya, Fransa ve İngiltere gibi devletlerin desteğini gören Ermenilerin şımardıklarını ve müstakil bir Ermenistan kurma hevesine kapıldıklarını, yoğun olarak II. Abdülhamit döneminden beri İmparatorluğun muhtelif yerlerinde isyanlar çıkardıklarını, Ermenilerin kendilerinin isyanlar

\footnotetext{
${ }^{44}$ Erol, ....Rüstem Bey, s. 21.

${ }^{45}$ Erol, ....Rüstem Bey, s. 21.

${ }^{46}$ Erol, ....Rüstem Bey, s. 22.
} 
sırasında masum insanları katlettikleri halde propagandaları sayesinde Batı dünyası nezdinde masum insanlar oldukları görüntüsünü sergilediklerini vurgulamıştır. Rüstem Bey, ABD'de yaşayan zencilerin ABD'nin düşmanları ile işbirliği yaparak Amerika'yı içeriden yıkmaya teşebbüs etmeleri halinde Amerikan yönetimi tarafindan bunların cezasız bırakılmayacağını ifade ettikten sonra, Osmanlı Devleti'nin de haklı olarak ülke içerisinde isyan çıkaran Ermeni tedhişçilere karşı bir takım ulusal güvenlik tedbirleri aldığının gerekçesini ortaya koymuştur. Vaziyet bundan ibaret olmasına rağmen, Ermenilerin masum gösterilmesinin, kabul edilebilir bir tarafı olamazdı. Bütün bunlara rağmen Ermeniler Batı kamuoyunda masum bir ırk olarak gösterilmekteydi. Rüstem Bey, ABD'de zencilere karş1 yapılmış olan vahşeti ve yine ABD'nin Filipinler'deki 'Water Cure ${ }^{47}$ işkencelerini ortaya koymuş ve bunu Türkiye'deki Ermeni olaylarıyla karşılaştırmıştır. Rüstem Bey ayrıca, Fransa ve İngiltere'nin ABD'yi savaşa sokmak için bir tuzak hazırladığını ve ABD'nin böylesi bir tuzağa düşmemesi için Amerikan yönetimine tavsiyede de bulunuyordu. Ancak, Rüstem Bey'in bu beyanatı hem ABD Başkanı Woodrow Wilson'1 hem de Amerikan devlet adamlarını kızdırmıştı. Özellikle Amerikalıların zencilere yaptığı zulüm ve katliamları, ayrıca 'Water Cure' işkencesini dillendirerek tenkit etmesi, Amerikalı yöneticiler tarafından, Amerikan içişlerine müdahale olarak algılanmıştır. Rüstem Bey'in beyanatına sinirlenen başta Wilson olmak üzere Amerikan yönetimi, Türkiye ile ilişkilerin kesilmesi için söz konusu beyanatı yeterli sebep saymışlardır. Bu süreçte Amerikan Hariciye vekili Bryan ve Robert Lansing devreye girerek ABD Başkanı Wilson'ı yatıştırmaya çalışmışlardır. Öyle ki, bu dönemde ABD'nin Türkiye ile ilişkilerini kesmesinin faturası ABD açısından iyi sonuçlar doğurmayacaktı. Çünkü Amerikalıların Anadolu'da 1820'lerden beri faaliyet gösteren misyonerleri ve özellikle Ermenileri eğittikleri çok sayıda okulları ve ticari alanda çıkarları bulunmaktaydı. ${ }^{48}$

Rüstem Bey'in beyanatından sonra Wilson, Hariciye vekiline 10 Eylül 1914'te şu mektubu göndermiştir:

"Sayın Hariciye vekili, dün gönderdiğiniz mühim şeyleri aldım. Karar vermeden evvel düşünmem için kendime biraz müsaade verdim. Sadece bir tanesi var ki, benim için çok aşikâr. Türk elçisi tamamıyla tahditleri aştı. Raporda ileri sürdükleri onun önüne serilirse ve raporun doğru olup

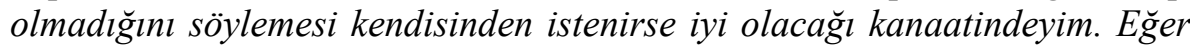
doğru değilse lûtfedip onun söylediklerini bize bildirin. Kati olarak onun

\footnotetext{
${ }^{47}$ The New York Times, 25 Eylül 1914.

${ }^{48}$ Erol, ... Rüstem Bey, s. 24-25.
} 
söylediğinin ne olduğunu ondan ögrendikten sonra, matlup bir kimse gibi onu daha uzun müddet ă̆ırlayıp ă̆ırlayamayacă̆ımızı düşünürüz."49

Wilson'1n mektubundan sonra Amerikan Hariciye vekili Rüstem Bey ile vermiş olduğu beyanat hakkında bir görüssme yapmıştır. Görüşmeden hemen sonra Rüstem Bey, gazeteye vermiş olduğu beyanatı ile ilgili Amerikan Hariciyesi'ne göndermek üzere 12 Eylül 1914 tarihli, muhtıra nitelikli, yeni bir yazı kaleme almıştır. Amerikan Hariciyesi'ne gönderdiği muhtıra nitelikli yazısında Ahmed Rüstem Bey, daha önceki beyanatıyla ilgili geri adım atmadığı gibi söylemlerinin doğruluğunu kanıtlar ifadeler kullanmıştır. Yeni yazısında, Türkiye'nin yıllardır çok kötü bir lisanla, küfür derecesinde Amerikan basınının sistematik hücumlarına maruz kaldığını, basının bu davranışı yüzünden Amerikan kamuoyunun Türkiye aleyhine zehirlendiğini belirtmiştir. Balkan Harbi'nin hemen sonrasında da hemen her Amerikan gazetesinin Türkiye aleyhine insafsız bir tarzda alay ve tahkirlerle yazılar neşretmekten geri durmadıklarını, bütün bunların ise Amerikan kamuoyunda Türk düşmanlığını perçinleştirdiğini ve yıllardan beri durmaksızın devam eden bu durum karşısında Türk milletinin bir üyesi olarak yapmış olduğu Türk elçiliği görevinin bütün bu suçlamalara karşıllk vermekten ibaret olduğunu ve harekete geçmekten başka bir çaresinin olmadığını ifade etmiştir. Rüstem Bey, Amerikan Hariciye vekiline gönderdiği muhtıra nitelikli yazısına şöyle devam etmiştir:

"Bu durumda Amerika Birleşik Devletleri'ne hücum ettiğimi ve hattâ onu tenkit ettiğimi söylemek pek doğru olmaz. Benim Amerikan hücumlarına karşı memleketimi koruduğum aşikârdır. Eğer benim müdafaa tarzım Amerika Birleşik Devletleri'nde muaheze edilecek bir takım hususlar olduğunu göstermek ve bunları belirtmek şeklinde tezahür etmişse, bu, benim bu memleket basınınin mevcut kusurlarını karşılayacak fevkalâde meziyetleri bulunan Türk halkı hakkında daha insaflı bir görüss sahibi olmağa ikna etmenin tek yolu olduğuna inandı̆̆ımdandır.

Diplomatik kaideleri ihlâl etmiş olabilirim fakat durum öyle idi ki, alışılmıs yollardan ayrılmış olmanın sadece mazur görülebilecek bir olay değil fakat resmiyetten ayrılmağı kılan meşru bir durum olduğuna şiddetle inaniyorum.

Ben Türkiye’ye, Amerika Birleşik Devletleri'ne ve nihayet insanlığa karşı manevî vazifelerimi tamamıyla yapmış olduğuma vicdanen müsterihim. "50

\footnotetext{
${ }^{49}$ Erol, ...Rüstem Bey, s. 26.

${ }^{50}$ Erol, ....Rüstem Bey, s. 29-30.
} 
Rüstem Bey'in bu muhtırası, ABD Başkanı Wilson'1 çileden çıkartmıştır. Bu yüzden Wilson, Ahmed Rüstem Bey'in derhal ABD'yi terk etmesini istemiştir. Durumu -kendisi de kızmış olan- Robert Lansing 14 Eylül 1914 tarihli mektubu ile resmiyete dökerek, Ahmed Rüstem Bey'in "istenmeyen adam" olduğunu ilan etmiştir. Türkiye'deki Amerikan çıkarlarını göz ardı etmenin doğru olmayacağına inandığından olsa gerek ki, Hariciye vekili Bryan'ın tavsiyesine uyularak Washington'ın Türkiye Büyükelçisi Ahmed Rüstem Bey'e 19 Eylül 1914'te, pişmanlık duyduğunu belirterek özür dilediği takdirde yaşanan tatsız hadiselerin unutulacağı ifade edilmiş ${ }^{51}$ ve bu tatsız hadiseden önce mevcut olan dostane ve candan münasebetlerin yeniden başlayacağını ve bunu bizzat Başkan Wilson'ın istediğini belirten mektup gönderilmiştir. ${ }^{52}$

Amerikan yönetimi tarafindan bu mektuptan sonra başta Wilson olmak üzere Amerikan yönetimindeki hemen herkes Rüstem Bey'in yumuşama gösterip özür dileyerek ABD'deki görevine devam edeceğini zannetmişlerdir. Oysa sonuç onlar için oldukça şaşırtıcı olmuştur. 20 Eylül 1914 tarihli cevabi mektubunda Ahmed Rüstem Bey, Başkan Wilson'in görüşlerine katılmadığını, dolayısıyla özür dilemeyeceğini ve 15 gün içerisinde ${ }^{53}$ ABD'den ayrılacağını bildirmiştir. ${ }^{54}$ Rüstem Bey'in bu tavrı karşısında Amerikan yönetimi hayretler içerisinde kalmıştır. Nitekim, Sait Halim Paşa'ya çektiği telgrafla durumu arz eden Rüstem Bey, 25 Ekim'de İstanbul'da olacağını ve kendisi gelmeden hiçbir diplomatik girişimde bulunulmamasını rica ettiği gibi eğer 25 Ekim'e kadar İstanbul'a gelmezse akıbetinin araştırılmasını istemiştir. Neticede Ahmed Rüstem Bey, İtalya üzerinden İstanbul'a sağ salim dönmüştür. ${ }^{55}$

\section{Ahmed Rüstem Bey Kendisini Anlattyor}

Ahmed Rüstem Bey'in birisi 1918'de diğeri 1922 yılında İsviçre'de ve bir diğeri de yine 1922 yılında kaleme aldığı üç Fransızca kitabı yayımlanmıştır. Birinci kitabının adı: "La Guerre Mondiale La Question Turco-Arménienne (1918, Berne)" (Cihan Harbi ve Türk-Ermeni Meselesi) olan Rüstem Bey'in ikinci kitabının adı:"La Crise Proche-Orientale et la Question des Détroits de Constantinople (1922, Cenevre)" (Yakındoğu Krizi ve İstanbul Boğazları Meselesi) üçüncü kitabının adı ise, La Paix d'Orient et l'accord franco-turc, "L'Orient et Occident" (1922) (Doğu Barış1 ve TürkFransız Antlaşması: Doğu ve Batı) tir. Yukarıdakilerin dışında Aralık 1919

\footnotetext{
${ }^{51}$ The New York Times, 25 Eylül 1914.

${ }^{52}$ Erol, ... Rüstem Bey, s. 36-37.

${ }^{53}$ Erol, ....Rüstem Bey, s. 38.

${ }^{54}$ The New York Times, 25 Eylül 1914.

${ }^{55}$ Erol, ...Rüstem Bey, s. 38-43.
} 
veya Ocak 1920'de kaleme almış olduğunu 8 Eylül 1920'deki milletvekilliğinden istifa gerekçesini sunduğu dilekçesinde belirttiği "Mahkeme-i Alem Huzurunda Türkiye" isimli eserinin bulunduğunu ifade etmiştir. Bilinenlerin dışında eserlerinin ve çok sayıda makalesinin olduğu tahmin edilmektedir.

Rüstem Bey, 1916'da İstanbul'da yazımını tamamladı $\breve{g}_{1}^{56}$ ve 1918 yılında İsviçre'de Fransızca olarak yayımlanan "La Guerre Mondiale La Question Turco-Arménienne (Cihan Harbi ve Türk-Ermeni Meselesi) adlı kitabının önsözünde Ermeni sorunu konusuna neden ilgi gösterdiğini anlatırken kendisi ile ilgili bilgiler de vermiştir. ${ }^{57}$

Rüstem Bey'in kitabının önsözünde yazdıklarından, Osmanlı Devleti'nin kendi ailesine karşı göstermiş olduğu teveccühten son derece memnun olduğunu bu yüzden de kendisini bu ülkeye ve Türklüğe adadığını ${ }^{58}$ bütün samimiyetiyle ortaya koyduğu anlaşılmaktadır. ${ }^{59}$

Rüstem Bey'in kitabının önsözünde ifade ettiği konulardan birisi de Müslüman oluşunu vurgulamasıdır. Ne zaman Müslüman olduğu konusunda kesin bilgiye ulaşılamamıştır. Ancak, kitabının önsözünde verdiği bilgiden anlaşıldığı kadarıyla sonradan kendi isteği ile Müslüman olmuştur. ${ }^{60}$

Amerikan kamuoyunda Türkiye aleyhine yürütülen Ermeni iddiaları karşısında sessiz kalmayıp ülkesini savunmuş olması ve akabinde Amerikan yönetimi tarafindan "İstenmeyen Adam" ilân edilmesi üzerine Washington Büyükelçiliği görevini bırakarak İstanbul'a dönen Rüstem Bey'in bu olaydan hemen sonra kaleme aldığı anlaşılan kitabında Ermeni iddialarına cevap verirken 1916 'da İstanbul'da olduğu ipucunu da vermektedir. ${ }^{61}$ Robert Lansing'ın ABD Başkanı Woodrow Wilson'a gönderdiği 10 Mayıs 1919 tarihli mektuptan anlaşıldığına göre Rüstem Bey'in bundan sonra Kahire'ye gittiği ve orada bir gazetede yazarlık yaptığ1 görülmektedir. ${ }^{62}$ Kahire, Rüstem Bey için yabancı sayılmazdı ${ }^{63}$ Zira yukarıda da izah edildiği üzere daha önce de Kahire'de gazetede çalışmıştı.

Netice itibariyle ABD'den döndükten sonra da boş durmayan Rüstem Bey, Birinci Dünya Savaşı sırasında Kahire'de gazetecilik yapmış, mütareke

\footnotetext{
${ }^{56}$ Ahmed Rüstem Bey, ...Türk-Ermeni Meselesi, s.138.

${ }^{57}$ Ahmed Rüstem Bey, ... Türk-Ermeni Meselesi, s. 8.

${ }^{58}$ Ahmed Rüstem Bey, ....Türk-Ermeni Meselesi, s. 11.

${ }^{59}$ Bkz. Ahmed Rüstem Bey, ...Türk-Ermeni Meselesi, s. 11-13.

${ }^{60}$ Ahmed Rüstem Bey, ...Türk-Ermeni Meselesi, s.12.

${ }^{61}$ Ahmed Rüstem Bey, ... Türk-Ermeni Meselesi, s. 138.

${ }^{62}$ Erol, ....Rüstem Bey, s. 44.

${ }^{63}$ BOA, Y.PRK.HR, Dosya No: 32, Gömlek No: 76, 1310.Z.12.
} 
yıllarında ise, Avrupa gazetelerinde Türkler lehine yazılar yazmıștır. ${ }^{64} 1918$ yılında Çukurova'nın işgali üzerine Çukurovalılar tarafından İstanbul'da kurulan Kilikyalılar Cemiyeti'nin hami azalığını veya bir anlamda şeref üyeliğini yapan ${ }^{65}$ Rüstem Bey, Milli Mücadele döneminde de Anadolu'da istiklâl mücadelesi veren Mustafa Kemal'in yanına gitmiştir. ${ }^{66}$

\section{Milli Mücadele'nin Önemli Simast: Ahmed Rüstem Bey Milli Mücadele Kadrosunda}

Ahmed Rüstem Bey'in Sivas'a gelerek Milli Mücadele kadrosuna dâhil oluşunu Mazhar Müfit Kansu 'Erzurum'dan Ölümüne Kadar Atatürk'le Beraber" adlı eserinde anlatmıştır. Mazhar Müfit, Birinci Dünya Savaşı'nda ordu kumandanı olan Halil Paşa ile İttihat ve Terakki meclisi idare azasından Küçük Tâlat Bey'in hapiste oldukları İstanbul'daki Bekir Ağa Bölüğü'nden, hapishane zabitlerinden Şadi Bey'in yardımı ile kaçarak Sivas yakınlarına geldiklerini, kendilerinin kabul beklediklerini, kabullerinin tabiî olduğunu ancak İttihatçı olmaları hasebiyle muhaliflerin yaygara koparabileceklerinin düşünülerek isimleri değiştirilip ordu karargâhında saklanmalarının sağlandığını anlattıktan sonra Ahmed Rüstem Bey'in Sivas'a gelişini de aynı bahiste vermiştir: "Vaşhington sefiri sabıkı Rüstem Bey (Rüstem Alfred Bey) de bir gün İstanbul'dan yola çıkt. Esas Polonyalı ve mühtedi olan bu zat bir Türk kadar hamiyetli ve vatana merbut olup bizimle beraber çalı̧̧mıs ve Ankara'ya da beraber gitmişti. Nihayet Ankara mebusu da oldu..."67

${ }^{64}$ Mazhar Müfit Kansu, Erzurum'dan Ölümüne Kadar Atatürk'le Beraber, C.1., Ankara, 1988, s.502; Gotthard Jaeschke, Kurtuluş Savaşı ile İlgili İngiliz Belgeleri, Ankara, 1986, s. 166.

${ }^{65}$ Taha Toros, Kurtuluş Savaşı'nda Çukurova, Ankara, 2001, s. 95,97. (Çukurova'yı hiç görmemiş olan Alfred Rüstem Bey, Kilikya'yı harita üzerinde tanlyordu. Ama bu bölgenin işgâline bütün gücü ile karşıydl. Bu açıdan, Ístanbul'daki cemiyetin merkezine zaman zaman uğrayıp onlara düşünceleriyle, moral vermekteydi. Çukurova'nın Türklere iadesini sağlayan Ankara Andlaşması üzerine (Orient Et Occıdent) dergisinde ilk ve ilmî bir makale yazan Ahmet Rüstem Bey oldu.) Toros, Kurtuluş Savaşı'nda Çukurova, s. 97-98. ( Zeki Sarıhan'ın Kurtuluş Savaşı Günlüğü adlı eserinde Rüstem Bey'in kurucu üyeler arasında yer aldığı belirtilmiştir).

${ }^{66}$ Erol, ....Rüstem Bey, s. 46.

67 'İsmi geçmekte olan Rüstem Bey (Alfred Rüstem Bey'dir), biz Sivas'ta iken Istanbul'dan kaçıp Sivas'a gelmiş ve bize gönüllü olarak iștirak etmiș ve bizden ayrılmamıştır. Gerçi Heyeti Temsiliye âzasından değildi. Fakat Karadă̆ ve Amerika sefaretlerinde, sefir olarak bulunmuş, umurı hariciyeye vakıf ve bilhassa Ingilizce, Fransizca, Italyanca lisanların bilhakkın bilen bir zat olduğundan, fikren ve kalemen bize hizmetten geri kalmamıştır.

"Intihapta Ankara mebusu oldu ve sonra suitefehhüm neticesi olarak mebusluktan istifa ile Mustafa Kemal Paşa'ya darldd ve İstanbul'da kaldl. Fakat Paşa kendisine maaş tahsisi suretiyle Rüstem Bey'e ölünceye kadar yardımda bulundu ve araları iyileşti." Kansu, ...Atatürkle Beraber, C.2., s. 340-341, 502. 
Nitekim, Rüstem Bey, İstanbul'dan ayrılarak Eylül başlarında önce Ankara'ya gelmiş oradan da 17 Eylül 1919'da Sivas'ta bulunan Mustafa Kemal'in yanına giderek ${ }^{68}$ 'Heyeti Temsiliye İstişare Kurulu Üyesi' (Temsil Heyeti Danıșma Kurulu Üyesi) olarak Milli Mücadele kadrosunda Mustafa Kemal'in yanında yer almıştır. Bu durumu da Mazhar Müfit şu sözleriyle ifade etmiştir:

"İçimizde Heyeti Temsiliye'ye dahil olmadĭg halde reyinden istifade edilmek üzere bazı zevat da vardı. Meselâ Rüstem Alfred Bey gibi." ${ }^{9}$

19 Eylül 1919'da Mustafa Kemal Paşa, Kâzım Karabekir Paşa ile telgraf başında haberleşmesi sırasında Rüstem Bey'in yanına gelişini şöyle anlatmıştır: "Koca diplomattan pek çok istifadeler ümit ediyoruz. Yalnız bizim çocukların bazen dili dolaşıp, Alfred demeleri mahcubiyetimize neden oluyor." $" 70$

Mahmut Goloğlu, "Sivas Kongresi" adlı eserinde Mustafa Kemal'in yakın arkadaşı olarak Rüstem Bey'den bahsederken, Türk milletini sevdiğini, Türk yurduna bağlı olduğunu ifade ettikten sonra Mustafa Kemal'in Rüstem Bey'i yanından hiç ayırmadığını ve hemen her konuyu Rüstem Bey'le istişare ettiğini belirtmiştir. ${ }^{71}$ Rüstem Bey'in Sivas'ta Mustafa Kemal'e söylemiş olduğu bir sözünü de kitabının başına koymuş olan Goloğlu, Mustafa Kemal Paşa ile Rüstem Bey arasında bu sözle ilgili cereyan eden ilginç konuşmayı şöyle anlatmıştır:

"Sivas Kongresi, daha çok, bir 'İhtilâl Komitesi'nin toplantısina benzeyecekti. Nitekim; Mustafa Kemal Paşa'nın yakın arkadaşı Alfred Rüstem Bey, bir konuşma sirasında bu gerçeğe değinerek 'Paşa, unutmayınız ki, burada Cemiyetler Kanununa göre teşekkül etmiş bir heyet değiliz. Bizim bir ihtilâl hey'etinden başka hüviyetimiz yoktur' diyecektir... Alfred Rüstem Bey'in sözlerini, Kayseri Delegesi Ahmet Hilmi Bey'in 'Sivas'a vardığımızda muhite hâkim olan ihtilâl havası idi' şeklindeki anlatışı da kuvvetlendiriyordu... (Fakat) Mustafa Kemal Paşa, kendisine 'Paşa, biz bir ihtilâl komitesiyiz. Bu hüviyetimizin bize verdiği cür'etle her şeyi yapabiliriz.' diyen yakın arkadaşı ve Hey'eti Temsiliye İstişarî Üyesi Alfred Rüstem Bey'e, açık ve kesin olarak 'Hayır Beyefendi, ben bunu yapamam' diye cevap vermis, delege olarak Sivas'a gelen İstanbul milli mücadelecilerinin başı, gizli Karakol Cemiyeti'nin kurucusu ve koyu İttihatçı Kara Vasıf Beye de 'Bizim aramızda ne Babıali Baskını'na, ne Yıldız

\footnotetext{
${ }^{68}$ Zeki Sarıhan, Kurtuluş Savaşı Günlüğü, C. II., Ankara, s.114.

${ }^{69}$ Kansu, ...Atatürkle Beraber, C.2., s.442.

${ }^{70}$ Beyoğlu, “...Ahmet Rüstem Bey...” (Yayımlanmamış tebliğ).

${ }^{71}$ Mahmut Goloğlu, Sivas Kongresi, s.62.
} 
Yağması'na ve ne de herhangi bir mâceraya yer verecek kimse yoktur. Müdafaai Hukuk Teşkilâtı'nın hedefi evvela memleketi düşman istilâsından kurtarmak, sonra da müstakil ve hür bir milletin lâylk olduğu devleti kurmaktır' demiştir."

Sivas'ta alınmış olan önemli kararların altında Rüstem Bey'in imzası da dâhil edilmiştir. $^{73}$

Rüstem Bey, yukarıda da belirtildiği üzere Sivas'ta gerçekleşen Heyet-i Temsiliye çalışmalarının tamamında "Heyet-i Temsiliye İstişare Kurulu Üyesi” olarak bulunmuştur. Heyet-i Temsiliye toplantıları 16 Kasım 1919'da başlamış ve 28 Kasım 1919'da sona ermiştir. 21, 24 ve 25 Kasım'da toplantı yapılmamıştır. Ahmed Rüstem Bey, 16, 17, 18, 19, 20, 22, 23, 26, 27 ve sonuncusunun yapıldığ $128 \mathrm{Kas} ı m$ 'da gerçekleşmiş olan bütün toplantılara katıldığ1 gibi bu toplantılarda görüşlerini de ifade etmiştir.

17 Kasım 1919'da yapılan toplantıda Mustafa Kemal Paşa, bir önceki toplantının (16 Kasım 1919) genel değerlendirmesi yapmış ve 16 Kasım toplantısında Meclis-i Mebusan'ın nerede toplanması gereği üzerine yapılan müzakerelerde, genel kanaatin İstanbul'da toplanması üzerinde yoğunlaştığını ifade etmiştir. Ancak, Mustafa Kemal Paşa, 17 Kasım toplantısında yeniden bu konuyu gündem maddesi olarak tartışmaya açmıştır. Çünkü kendisi de Meclis'in İstanbul'da toplanmasının tehlikeli olduğu düşüncesine sahiptir. 17 Kasım 1919'da Saat 2.30'da başlayan toplantının Birinci Celse'sinde açılış konuşmasını yapan Mustafa Kemal'den sonra konuşan Mümtaz Bey'in peşi sıra söz alan Ahmed Rüstem Bey, tam da Mustafa Kemal Paşa'nın düşüncesinde olan, yeni bir fikri ileri sürmüştür. Rüstem Bey, Meclis'in İstanbul dışında ve Milli Meclis (Asamble Nasyonal) şeklinde toplanması gerektiği fikrini ortaya atmıştır. Neticede Mustafa Kemal Paşa'nın görüşleri de Rüstem Bey ile aynıdır. Zaten, Mustafa Kemal Paşa, İstanbul'da toplanacak bir meclisin güvenli olmayacağ 1 hususunu 20 Ekim 1919'da Amasya'da Salih Paşa ile yapmış olduğu görüşmede dile getirmişti. Ancak bu konu, daha sonra İstanbul Hükümeti tarafindan Anayasa'ya aykırı olacağı gerekçesiyle kabul görmemiş, Mustafa Kemal Paşa'da bu konuda israr etmemişti.

Görüldüğg̈ üzere Ahmed Rüstem Bey, "Heyet-i Temsiliye İstişare Kurulu Üyesi" olarak Heyet-i Temsiliye toplantılarında etkin faaliyetlerde bulunmuştur. Ayrıca Heyet-i Temsiliye tarafından milli harekete zararlı akımlara karşı, her türlü yayın yapmak ve konferanslar vermekle yükümlü

\footnotetext{
${ }^{72}$ Goloğlu, Sivas Kongresi, s. 61-63.

${ }^{73}$ Kemal Atatürk, Nutuk, C.I., İstanbul, 1981, s. 274; Kansu, ...Atatürkle Beraber, C.2., s.446.
} 
bir propaganda kurulu kurulmuş ve bu kurulun içerisinde Mazhar Müfit ve Hüsrev Sami ile birlikte görevlendirilmiştir. ${ }^{74}$

Mustafa Kemal-Harbord görüşmesi sırasında da Rüstem Bey, Hüseyin Rauf ve Bekir Sami beylerle birlikte Mustafa Kemal Paşa'ya refakat etmiştir. ${ }^{75}$ Sivas'a Mustafa Kemal Paşa ile görüşmek için gelen Suriye'deki Fransız Yüksek Komiseri’nin temsilcisi Mösyö Briand'a Adana, Antep, Urfa ve Maraş gibi vatan topraklarından vazgeçilmeyeceği kesin bir dille anlatılırken Rüstem Bey, daha uç bir söylemle Fransızların bir an önce Suriye'yi bile tahliye etmelerini istemiştir. ${ }^{76}$

Rüstem Bey’in Mustafa Kemal Paşa ile Birlikte Sivas'tan Ankara'ya Yolculuklart

Sivas'tan Ankara'ya yolculuk hazırlıklarında nasıl ve kimlerle gidileceğini Mazhar Müfit'le konuşan Mustafa Kemal, arabayla gidecek olanları sayarken: “...Şimdi kimler var? Rauf Bey, misafirimiz Alfred Rüstem Bey, sen, Şeyh Fevzi Efendi..."77 gibi isimleri zikretmiş ve nihayetinde Mustafa Kemal Paşa, Rüstem Bey’i kendi arabasına alarak birlikte Ankara'ya gitmişlerdir. ${ }^{78}$

Ahmed Rüstem Bey, Mustafa Kemal Paşa ile birlikte 27 Aralık 1919'da Ankara'ya gelmiş, Ankara'daki Heyet-i Temsiliye toplantılarına da katılmış ve daha sonra İstanbul'da toplanan son Osmanlı Meclis-i Mebusan'ina önce Çorum'u temsilen katılması düşünülmüş ${ }^{79}$ fakat daha sonra Heyet-i Temsiliye, Ankara Valiliği'nden Ahmet Rüstem Bey'in merkez livadan mebus seçilmesinin sağlanmasını istemiş ve sonuçta Rüstem Bey, Ankara mebusu $^{80}$ olarak Meclis-i Mebusan'a iştirak etmiştir. 16 Mart 1920'de gerçekleşen İstanbul'un işgali, bu sırada işgal kuvvetlerinin hoyrat davranışları, Mebusan Meclisi üyeleri ile diğer ileri gelen zevata karşı ağır ve hakaret içeren davranışlar sergilenerek tutuklanmaları üzerine, Rüstem Bey, İtalyanların gizli şekilde yardımı sayesinde Ahmed Muhtar ve Memduh Şevket ile beraber tutukluluktan kurtarılarak İtalyanların refakatinde Ankara'ya Mustafa Kemal Paşa'nın yanına getirilmiştir. ${ }^{81}$ Rüstem Bey, bundan sonra Ankara'da toplanan Birinci Büyük Millet Meclisi'ne Ankara

\footnotetext{
${ }^{74}$ Sarıhan, Kurtuluş Savaşı Günlüğü, C.II., s. 117.

${ }^{75}$ Salâhi R. Sonyel, Türk Kurtuluş Savaşı ve Dış Politika I, Ankara, 1995, s. 159, dn. 3.

${ }^{76}$ Kansu, ...Atatürkle Beraber, C.2., s. 461.

${ }^{77}$ Kansu, ....Atatürkle Beraber, C.2., s. 482.

${ }^{78}$ M. Cemil Özgül, Heyet-i Temsiliye'nin Ankara'daki Çalışmaları (27 Aralık 1919-23 Nisan 1920), Ankara, 1989, s. 49.

${ }^{79}$ Sarıhan, Kurtuluş Savaşı Günlüğü, C.II., s. 166.

${ }^{80}$ Sarıhan, Kurtuluş Savaşı Günlüğü, C.II., s. 227.

${ }^{81}$ Beyoğlu, “...Ahmet Rüstem Bey...” (Yayımlanmamış tebliğ).
} 
mebusu olarak katılmıștır. Rüstem Bey, kısa süreliğine Dış İşleri Bakanlığg vekilliğinde de bulunmuştur. ${ }^{82}$

\section{Rüstem Bey Mustafa Kemal'e Düello ${ }^{83}$ Teklif Ediyor}

Bir gün içerisinde ordu komutanlarının bulunduğu yaklaşık 20 kişilik bir grupla yemek esnasında et yemeği yendikten sonra Mustafa Kemal'in karşısında oturan Rüstem Bey sigara yakar. Mustafa Kemal ise, Rüstem Bey'e acele etmemesini, yemeğin daha devam edeceğini söyler. Sigarasını söndüren Rüstem Bey alınganlık göstererek yemekten ayrılır. Odasına çekilen Rüstem Bey'in yanına giden Mazhar Müfit Bey, Rüstem Bey'in son derece gergin olduğunu gözlemler. Paşa'nın hareketi ile kırıldığını ifade eden Rüstem Bey, Mazhar Müfit'e kırılan onurunun telafisi için Paşa ile düello etmesi gerektiğini söyler. Durum Mustafa Kemal Paşa'ya bildirilir. Olayı ciddiye almayan Mustafa Kemal, Rüstem Bey'in kendisini yanlış anladığını ifade eden gönül alıcı sözler sarf eder. Kısa süre sonra vaziyet eski şeklini alır. ${ }^{84}$

Mazhar Müfit tarafindan anlatılmış olan bu hadiseyi dönemin diğer tanıkları da teyit etmişlerdir. ${ }^{85}$

Ahmed Rüstem Bey'in daha önce de Hariciye'de diplomatlı yaptığı dönemde Atina Sefareti'nde İkinci Kâtiplik görevini yürütürken Türklüğe hakaret eden Yunan Binbaş1 Erjiropolo'nun düello teklifini kabul ettiği ve söz konusu düellonun Paris'te gerçekleştiği, Osmanlı Devleti'nin Paris Sefareti'nden Hariciye Nezareti'ne gönderilen telgraflardan anlaşılmaktadır. ${ }^{86}$ Paris’teki düelloda taraflara bir şey olmamıştır. Ancak, Rüstem Bey'in diplomatlık yaptığı dönemde yine bir Yunanlı ile düellosu

\footnotetext{
${ }^{82}$ Kemal Arıburnu, Sivas Kongresi: Samsun'dan Ankara'ya Kadar Olaylar ve Anılarla, Ankara, 1997, s. 249.

${ }^{83}$ Düello:"Eskiden bazı ülkelerde bir hakareti kanla temizlemek için iki kişi arasında ve şahitler önünde yapılan silâhlı çarpışma. Eski çağlarda iki kişi arasında ve herkesin önünde yapılan silahlı çarpışmalar, savaşlara başlarken, dâvâlı şefler arasında bir gösteriş çarpışması şeklinde ya da savaşı kızıştırmak için yapılırdı. Şahıslar arasındaki çeşitli anlaşmazlıkları düello ile ve meşru bir şekilde halletmek şekline, Orta çağın derebeylik devrinde rastlanır. Bu çağda salgın bir hal alan düello, bir âdet ve moda haline gelmiş, özellikle XVII. yüzyıl Fransasında aristokrat ailelerin pek çok kaybına sebep olmuştur. Sonradan düello yapmak, hükümetler tarafindan yasak edilmiş, böylece, bu keyfi adam öldürmenin önü alınmıştır." (http://www.baktabul.com/nedir/96987-duello-nedir-duello-hakkinda-dueolla-tanimi.html, Erişim Tarihi: 1 Haziran 2008).

${ }^{84}$ Kansu, ...Atatürkle Beraber, C.2., s.509, 510-511.

${ }^{85}$ Arıburnu, Sivas Kongresi..., s. 249-250.

${ }^{86}$ BOA, Y.PRK.A., Dosya No: 7, Gömlek No: 91, 130.M.24. (Alfred Bey ile Yunan Binbaşı Erjiropolo arasında Paris'te gerçekleşen düelloda tarafların attıkları kurşunlar isabet etmemiş daha sonra da barışmışlardır.).
} 
gerçekleșmiştir. Ahmed Rüstem Bey'in bu defa düello yaptığı şahıs, Yunanlı bir diplomattır. Rüstem Bey, Türklük aleyhinde sözler sarf ettiği için O'nu düelloya davet etmiş ve Yunanlı diplomatı ağır yaralamıştır. Bu Yunanlı zat, düello sırasında almış olduğu yaradan dolayı kısa süre sonra ölmüştür. Düello sırasında Rüstem Bey de boynundan yaralanmış ve bu yara boynunda iz bırakmıștır. ${ }^{87}$

Rüstem Bey'in birinci düellosu hakkında arşiv belgelerinde bilgi yer alırken $^{88}$ diğer düellosu hakkında belgeye rastlanmamıştır. Ancak, Rüstem Bey, "La Guerre Mondiale La Question Turco-Arménienne (1918, Berne)" (Cihan Harbi ve Türk-Ermeni Meselesi) adlı kitabının önsözünde “...bu ülkenin ve Türk halkının şerefini korumak için iki kere düelloda bile döğ̈̈ştüm ve Türk-Yunan savaşına gönüllü olarak katıldım. " ${ }^{, 89}$ diyerek bahsi geçen diğer düelloyu da teyit etmiştir.

\section{Ahmed Rüstem Bey Mustafa Kemal ile Birlikte Divan-ı Harp Tarafindan İdama Mahkum Edilenler Arasında}

Divan- Harp, Mustafa Kemal Paşa'nın ve bazı arkadaşlarının idamına karar vermişti. Konu, The New York Times'ın Londra çıkışlı 15 Mayıs 1920 tarihli "Kemal ölüm cezasına çarptırılırken diğer iki Türk de aynı cezaya çarptırıldı" başlıklı haberi ile verilirken ${ }^{90}$ İstanbul'da neşrolunan "Peyâmi Sabah" gazetesinin 13 Mayıs 1336 tarihli nüshasında ise, 'Mustafa Kemal ve hempalarının idamı' serlevhasıyla neşredilmiştir.

Ahmed Rüstem Bey, yukarıda da izah edildiği üzere Sivas'ta Mustafa Kemal Paşa'nın yanına gitmiş ve Milli Mücadele'nin kritik sürecinde önemli karaların altına imza atmıştır. Ayrıca, İstanbul'daki son Osmanlı Meclis-i Mebusanı'nda Ankara Mebusu olarak hizmet vermiş daha sonra, Ankara'da Büyük Millet Meclisi'nin açı1ışına katılmış ve bu mecliste de mebus olarak görev almıştır. Bütün bunların yanı sıra Rüstem Bey’in Mustafa Kemal Paşa ile birlikte idama mahkûm edilenler arasında yer almış olması, O’nu,

${ }^{87}$ Arıburnu, Sivas Kongresi..., s.250.

${ }^{88}$ BOA, Y.PRK.A., Dosya No: 7, Gömlek No: 91, 130.M.24

${ }^{89}$ Ahmed Rüstem Bey, ...Türk-Ermeni Meselesi, s. 11.

${ }^{90}$ The New York Times, 15 Mayıs 1920. Gazete Divan-1 Harb'in verdiği karar ile Mustafa Kemal Paşa'nın gıyabında idam'a mahkum edildiğini, Ahmed Rüstem Bey ile Ali Fuad Paşa'nın da aynı cezaya çarptırıldığını belirtmiştir. (Mustapha Kemal, leader of Turkish Nationalist forces in Asia Minor, was condemned to death at an extraordinary corut-martial held in Constantinople on Wednesday, according to a dispatch from the Turkish capital to the Exchange Telegraph Company. As he did not appear for trial he was found guilty by default. Others sentenced were Ali Fuad Pahsa, former commander of the Twentieth Turkish Army Corps, and Alfred Rustem Bey, former Turkish Ambassador to the United States.) The New York Times, 15 May1s 1920. 
Osmanlı dönemindeki sıra dıșı diplomatlığının dışında milli mücadelenin de istisna simalarından birisi yapmıştır.

\section{Ahmed Rüstem Bey'in Milletvekilliğinden İstifası ve Avrupa'ya Gidişi}

“Osmanlı Imparatorluğu'nun Amerika Büyük Elçisi A. Rüstem Bey" isimli eserinde Mine Erol, Rüstem Bey'in alıngan mizacından dolayı bir başka (bilinmeyen) sebeple yeniden Mustafa Kemal Paşa ile arasının bozulduğunu ve 8 Eylül 1920'de milletvekilliğinden istifa ederek Avrupa'ya yerleştiğini, bundan sonra hiçbir vazife almayarak sadece Avrupa gazetelerine İstanbul ahvali hakkında yazı yazmakla meşgul olduğunu ve 1935 yılında 73 yaşında hayata gözlerini yumduğunu Mahmut Goloğlu'nun 'Sivas Kongresi' adlı eserinden alıntı yaparak belirtmiştir. ${ }^{91}$ Aslında Rüstem Bey ile ilgili şu ana kadar ortaya çıkartılmış olan belgeler Mine Erol'un Mahmut Goloğlu'ndan alıntı yaparak vermiş olduğu bilgileri teyit eder niteliktedir. Ancak Ahmed Rüstem Bey'in Mustafa Kemal Paşa ile bu tarihten sonra da diyalogunun sürdüğü ve yurt dışında önemli görevlerde bulunduğu, yine belgelerden anlaşılmaktadır. Örneğin, 8 Eylül 1920'de milletvekilliğinden istifa ederek Avrupa'ya yerleştiği söylenen Rüstem Bey'in, İngiliz belgelerinden anlaşıldığına göre bu tarihlerde Mustafa Kemal Paşa'yı temsilen Moskova'da görüşmelerde bulunduğu anlaşılmaktadır. ${ }^{92}$ Ayrica, 19-20 Kasım 1920 tarihlerinde bizzat Mustafa Kemal tarafindan İçişleri Bakanı Câmi Bey ile birlikte önemli temaslarda bulunmak üzere Roma'da görevlendirildiği ve bu seyahate büyük önem verildiği Maslahatgüzâr Ferruh Bey'den Hâriciye Nâzırı Safa Bey'e gönderilen resmi yazıdan anlaşılmaktadır. ${ }^{93} \mathrm{Bu}$ görevlendirmeden tam bir yıl sonra Kasım 1921'de Ahmet Riza, Cavit, Sudi, Ziya, Ahmet İhsan, Reşit Saffet, Harun Aliçe, Hüseyin Hilmi, Mahmut Muhtar, Çürüksulu Mahmut, Salih Manir beyler ile Ahmed Rüstem ve Vehip Paşa'nın Roma Büyükelçisi Galip Kemali Bey'in kaldığı otelde bir araya gelerek Paris Konferansı için İtalyanlar tarafından Konferansa sunulmak üzere bir muhtıra hazırladıkları görülmektedir. ${ }^{94} 1922$ yılı Eylül'ünde de Ahmed Rüstem Bey'in Mustafa Kemal ile diyalogunu devam ettirdiği anlaşılmaktadır. 1922 yılı Eylül’ünde

${ }^{91}$ Erol, ... Rüstem Bey, s. 52. (Goloğlu, Sivas Kongresi, s. 62.).

${ }^{2}$ Bilâl N. Şimşir, İngiliz Belgelerinde Atatürk (1919-1938), C. II., Ankara, 1975, s. 275. (Moskova görevlendirmesinde önce de 1920 yılı Temmuz'unda Rüstem Bey'in Mustafa Kemal tarafından Paris'e gönderildiği anlaşılmaktadır. Amiral Robeck tarafından Earl Curzon'a çekilen 15 Temmuz 1920 tarihli acil ve gizli telgrafta Ahmed Rüstem Bey'in Resad Nihad'la beraber barış konferansını izlemek üzere Mustafa Kemal Paşa'yı temsilen Paris'te bulundukları ve bu iki milliyetçi şahsın faaliyetlerinin takip edilmesi belirtilmiştir.) Şimşir, İngiliz Belgelerinde Atatürk..., C. II., s. 213.

${ }^{93}$ Belgelerle Mustafa Kemal Atatürk, s. 164. ( BOA, HR. SYS, 2607/6_17).

${ }^{94}$ Sarıhan, Kurtuluş Savaşı Günlüğü, C.IV., s. 155. 
Rüstem Bey tarafindan Mustafa Kemal'e uzun bir mektup gönderilmiștir. Rüstem Bey tarafından gönderilen mektupta, İtilaf Devletleri'nin İstanbul'a karşı herhangi bir hareketten kaçınılmasını ihtar eden notalarının blöf olduğunu, İngiltere'nin artık savaşacak durumda olmadığını ve Fransa'nın İngiltere ile ortak hareket edemeyeceğini dolayısıyla Mustafa Kemal'in yapması gereken en doğru hareketinin, cüretli davranarak askerî harekâta devam etmek olacağı fikrini ileri sürmüştür. ${ }^{95}$

8 Eylül 1920'de Ankara Milletvekilliğinden istifa eden Rüstem Bey'in Meclis Genel Kurulu'nda okunan istifa dilekçesi ise şöyledir: Dokuz on ay önce Türkiye'yi savunmak için 'Mahkeme-i Alem Huzurunda Türkiye' başlığı altında İstanbul'da bir kitap yayınladığını, ancak bu eserler beş yüz tane basilip hemen hepsi Istanbul'da Türk ve yabancl resmi makamlara dă̆ıtılması nedeniyle Türk ve özellikle yabancı kamuoyunun bundan habersiz kaldığını, bu itibarla eserini kâfi miktarda yeniden bastırmak üzere Italya'ya gitmeyi düşündügünü, Türkiye'ye son ve bekli de klymetsiz saylmayacak bir hizmette bulunup, ondan sonra rahat ölmek düşüncesine dayanan bu niyetine fevkalade bir ehemmiyet verdiğini, Italya'ya gitmek düşüncesinin diğer bir sebebi de iyi Fransizca ve Íngilizce bilmesi ve dolaylsiyla pek çok ehemmiyeti haiz propaganda konusunda Avrupa ve Amerika gazete ve dergilerine yazllar yazmak suretiyle bu hizmetin ancak İtalya ve İsviçre'de yapılabileceğine inanması olduğundan Ankara milletvekilliğinden istifasinın kabulü ve gitmesine müsaade buyrulmasın istediğ ${ }^{\prime \prime}{ }^{96}$

Yukarıda da ifade edildiği gibi Rüstem Bey, her ne sebeple Türkiye'den ayrılmış olursa olsun, Türkiye ile ilgili resmi girişimlerde bizzat Mustafa Kemal Paşa tarafından görevlendirilmiş ve bu görevlendirmelerde Rüstem Bey de üzerine düşeni yapmıştır.

\section{Atatürk Tarafindan Rüstem Bey'e Ömür Boyu Maaş Bağlantyor}

2 Ekim 1920 tarihli Kanun Layihası ile büyük Türk şairi Abdülhak Hamid, Meclis-i Ayan üyeliği yapmış olan tarihçi Abdurrahman Şeref ve Rüstem Bey'e ömür boyu 5 bin kuruş maaş tahsis edilmiştir. ${ }^{97}$ Rüstem Bey, kendisine yönelik bu taltifi öğrenir öğrenmez 4 Kasım 1920'de Heyet Vekilleri Riyaset-i Celilesi'ne teşekkür eden bir mektup yazmıştır. ${ }^{98}$

\footnotetext{
${ }^{95}$ Sarıhan, Kurtuluş Savaşı Günlüğü, C.IV., s. 670.

${ }_{96}^{96}$ Beyoğlu, “...Ahmet Rüstem Bey..., (Yayımlanmamış tebliğ).

${ }^{97} \mathrm{BCA}, 030.18 .1 .1 / 6.46 .5,18 / 1 /(1) 339$.

${ }^{98}$ BCA, 030.18.1.1/6.46.5, 21 Şubat (1)339.
} 
Ancak, Rüstem Bey'in bu para, ya bir şekilde eline ulaşmamış ya da yeterli gelmemiş olacak ki, 2 Ocak 1921'de Roma'dan Ankara'ya göndermiş olduğu mektubunda para sıkıntısı çektiğini ve hasta olduğunu belirtmiştir. Rüstem Bey, mektubunda, kalıcı bir hastalığı olduğunu ve bunun da bilindiğini ima eden bir üslup kullanmıştır. ${ }^{99}$ Neticede, kendisine ömür boyu maaş bağlandığını beyan eden taltif hadisesinden ve Roma'dan yazmış olduğu mektuptan yaklaşık bir yıl sonra yani 26 Kasım 1921'de Rüstem Bey'e İcra Vekilleri Heyeti kararı ile 500 lira gönderilmiştir. ${ }^{100}$

26 Kasım 1921 tarihli kararname'de “Washington sefir-i sabıkı Ahmed Rüstem Bey'e maarif-i mesture tertibinden şimdilik 500 lira gönderilmesi.." ${ }^{\prime 101}$ şeklinde yazılmış olan ifadeden bu tür yardımların devam ettirildiği anlaşılmaktadır. 2 Kasım 1921 tarihli mektubunda, kalemi ile Türkiye'ye hizmet etmeye devam ettiğini ${ }^{102}$ belirtmesi Rüstem Bey'in Avrupa'daki çeşitli dergi ve gazetelere Türkiye'nin haklarını savunan makaleler yazmaya devam ettiğini göstermektedir.

\section{Sonuç Yerine}

Rüstem Bey ile ilgili gerek Başbakanlık Osmanlı Arşivi, Başbakanlık Cumhuriyet Arşivi gerekse Dişişleri Bakanlığı Arşivi, Cumhurbaşkanlığı Arşivi ile TBMM Arşivi'nde bulunan belgeler bu makale içerisinde değerlendirilmiştir. Çeşitli ansiklopedi ve diğer yayınlarda, 1921 yılından sonra Rüstem Bey'in ölüm yılı olarak verdikleri 1935 yılına kadar Avrupa'da yaşadığı bilgisi verilmiştir. Ancak hangi Avrupa ülkesinde ne kadar bulunmuştur? Türkiye'ye hangi aralıklarla gelmiştir? Nerede ve tam tarih olarak ne zaman vefat ettiği konusunda birinci elden kaynak olabilecek bir belge veya bilgiye rastlanmamıştır.

Rüstem Bey'in 2 Ocak 1921'de Roma'dan Ankara'ya göndermiş olduğu mektubunda hasta olduğunu vurgulamıştır. ${ }^{103}$ Rüstem Bey bu mektubunda sanki önemli bir hastalığının olduğu ayrıntısını veriyor gibidir ve uzun yıllar bu hastalığından muzdarip olduğu anlaşılmaktadır zira 24 Şubat 1934'te İstanbul'dan Ankara'ya Dahiliye Vekâleti'ne yazdiğı mektubunda halâ tedavi gördüğünü ancak, bunun sağlığında bir iyileşme gerçekleştirmediğini ifade etmiştir. ${ }^{104}$

\footnotetext{
${ }^{99}$ BCA, 030.18.1.1/6.46.5, 2 Kanun-i sâni 1337.

${ }^{100}$ BCA, 030.18.1.1/4.39.2, 26 Teşrin-i sâni (1)337.

${ }^{101}$ BCA, 030.18.1.1/4.39.2, 26 Teşrin-i sâni (1)337.

${ }^{102}$ BCA, 030.18.1.1/6.46.5, 2 Kanun-i sâni 1337.

${ }^{103}$ BCA, 030.18.1.1/6.46.5, 2 Kanun-i sâni 1337.

${ }^{104}$ CBA, A: VII-2-d, D: 93, F: 246.
} 
Ayrıca, Evlilik yapmış mıdır? Çocukları var mıdır? Bütün bunlar bilinmeyenler arasındadır. ${ }^{105} \mathrm{Bu}$ konuları aydınlatmak için Emekli Sandığı arşivlerinde yaptığımız araştırmada Rüstem Bey ile ilgili her hangi bir kayda rastlanamamıştır.

Rüstem Bey ile ilgili ortaya konulması gereken olgulardan birisi de gerçekte neden milletvekilliğinden istifa ettiği hususudur. Bu konu ile ilgili her ne kadar Büyük Millet Meclisi'nde istifasının gerekçesi ortaya konulmuşsa da gerçek sebebin ne olduğu hususunda kesin bir bilgiye ulaşılamamıştır.

Yine Rüstem Bey ile ilgili ortaya konulması gereken hususlardan birisi de O'nun Misır'da gazetecilik yaptığı yıllardır. 1903 ila 1909 arasında Kahire'de gazetecilik yaptığı bilinmektedir. II. Meşrutiyet sonrasında İstanbul'da İttihat ve Terakki'nin güçlendiği bir dönemde Rüstem Bey'in yeniden aslî ișine yani Hariciye'deki görevine döndüğü görülmüș hatta bu dönemde "Büyükelçi" sıfatı ile taltif edilerek önce Çetine (Karadağ) Büyükelçiliği'ne daha sonra ise Washington Büyükelçiliği görevine getirildiği, sorunlu Washington Büyükelçiliği görevinden sonra Birinci Dünya Harbi sırasında yeniden Mısır'a gittiği ve orada gazetecilik yaptığı çeşitli belgelerden anlaşılmaktadır. Bu yüzden Ahmed Rüstem Bey'in Mısır' da bulunduğu değişik tarihlerde hangi gazete/gazetelerde görev yaptığ ve yazmış olduğu makaleleri, bilinmeyenler arasındadır. Dolayısıyla Rüstem Bey'in Kahire yılları ve bu süreçte Kahire'deki irtibatları ile hangi gazete ve dergilerde yazılar neşrettiği hususunun ortaya konulması gereklidir.

İttihatçıların Kahire'de şube açtıkları ve burada 'Kanunu Esasi', 'Basiretül Şark', ve 'Hak' (bir ara Abdullah Cevdet'in 'Içtihad' dergisi) adlı gazetelerin yayımlandı ${ }^{106}{ }^{106}$ bilinmektedir. Zira Rüstem Bey’in Kahire yılları, O'nun Jön Türkler kadrosu içerisindeki yerini ortaya koyması bakımından önem taşımaktadır. Rüstem Bey'in 24 Nisan 1901'de The New York Times'ın Londra muhabirine verdiği beyanatta Padişah'1 ağır bir şekilde eleştirdikten ${ }^{107}$ sonra “...Kendimi Genç Türk Partisi ile tanımlamıyorum, fakat onlara ya da gerçek Türk reformunu destekleyen herhangi bir

105 “Kurtuluş Savaşı'nda Çukurova” adlı Kültür Bakanlığı yayınları arasından çıkan Taha Toros'a ait eserde Toros, Rüstem Bey'in Eylül 1934'te öldüğünü, kendi arşivinde Rüstem Bey'e ait bazı mektupların bulunduğunu ve Müslüman oluşuna dair belgelerin bulunduğunu ifade etmiştir. (Toros, Kurtuluş Savaşı'nda Çukurova, s. 98, dn.7.)Taha Toros ile yaptığım görüşmede kendisinden eserinde bahsettiği belgeleri istediğim de, söz konusu ettiği belgelerin şu anda kendisinde bulunmadığını söylemiștir.).

${ }^{106}$ Muzaffer Sencer, Türkiye'de Siyasal Partilerin Sosyal Temelleri, İstanbul, 1971, s. 24.

${ }^{107}$ The New York Times, 24 Nisan 1901 
programa yönelik yoğun bir sempatim var" ${ }^{108}$ demesi, Abdülhamit yönetimine karşı reformları destekleyen ve o dönemin bu konudaki tek örgütü olan Jön Türkleri adres göstermesi dikkat çekicidir. Ayrıca, Rüstem Bey'in II. Meşrutiyet'in ilânından sonra Osmanlı yönetimince yeniden el üstünde tutulması, 1909'da Washington Maslahatgüzarlı̆̆g'na tayin edilmesi, 1910 yılında Hariciye Nezareti tarafından 'soruşturmacı' olarak görevlendirilmesi, akabinde taltif edilerek Çetine (Karadağ) Büyükelçiliği'ne getirilmesi $^{109}$ ve son olarak Washington Büyükelçisi olarak ABD'ye gönderilmesi ${ }^{110}$ olgusunun dikkatle analiz edilmesi gerekir. Çünkü bahsedilen bu süreç İttihatçıların zirvede oldukları dönemdir.

Son olarak, Rüstem Bey'in Avrupa'da çeşitli dergi ve gazetelere yazmış olduğu makaleler de incelenmeye muhtaçtır.

Hayatı boyunca Türklük ve Türkiye savunuculuğu yapmış olan yakın dönemin bu istisna insanının bir taraftan sıra dıșı kișiliği diğer taraftan ise, hem Osmanlı dönemi hem de Milli Mücadele döneminde üstlendiği görevleri ve bu görevleri sırasında Türkiye'ye ve Türk Milleti'ne olan bağlılığı, O'nu, Türk tarihinin önemli şahsiyetleri arasına kattığı gibi yeni nesil tarafından da bu önemli şahsiyetin daha iyi tanıtılmasını zorunlu kılmaktadır.

${ }^{108}$ The New York Times, 24 Nisan 1901.

${ }^{109}$ BOA, İ.HR, Dosya No: 427, Gömlek No: 1329/Z-06, 1329.Z.21

${ }_{110}$ BOA, İ.MBH, Dosya No: 15, Gömlek No: 1332/C-022, 1332.C.22; BOA, İ.MBH, Dosya No: 15, Gömlek No:1332/C-26, 1332.C.25. 


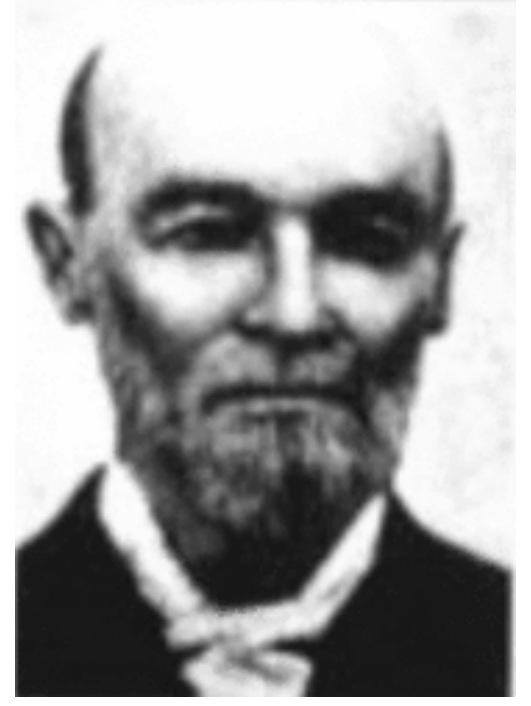

Ahmed Rüstem Bey

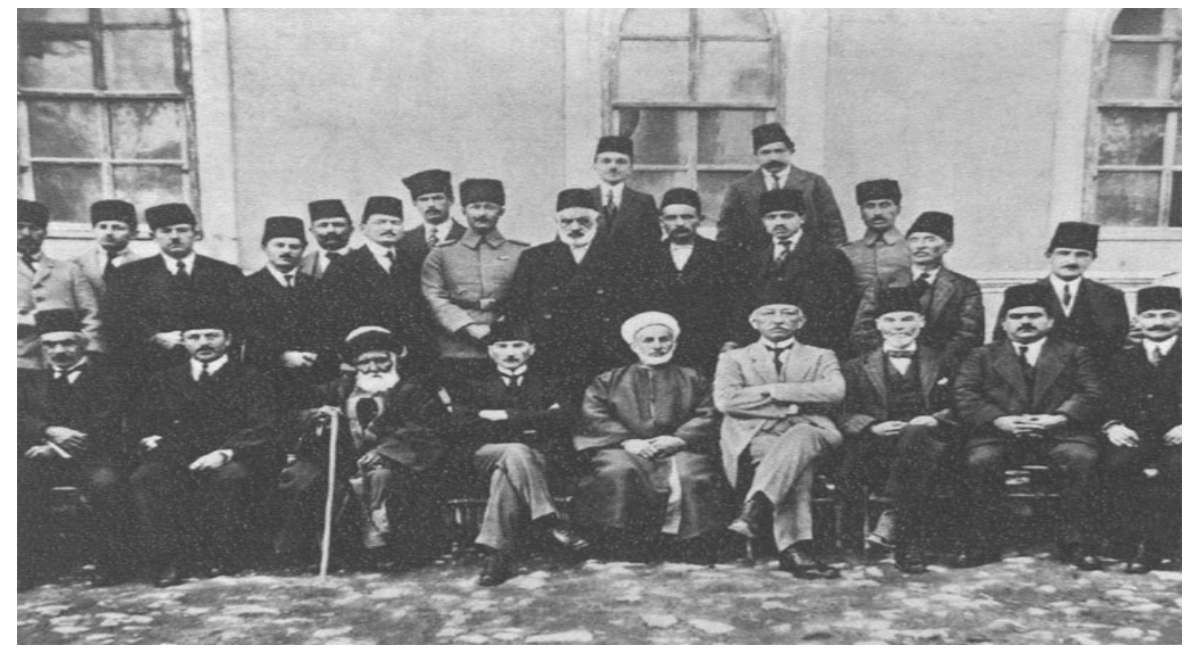

Sivas Kongresi Sırasında Kongre Binası Önünde Çektirilen Hatıra Fotoğrafı (Ahmed Rüstem Bey, Önde Oturanlardan Sağdan Üçüncü) 


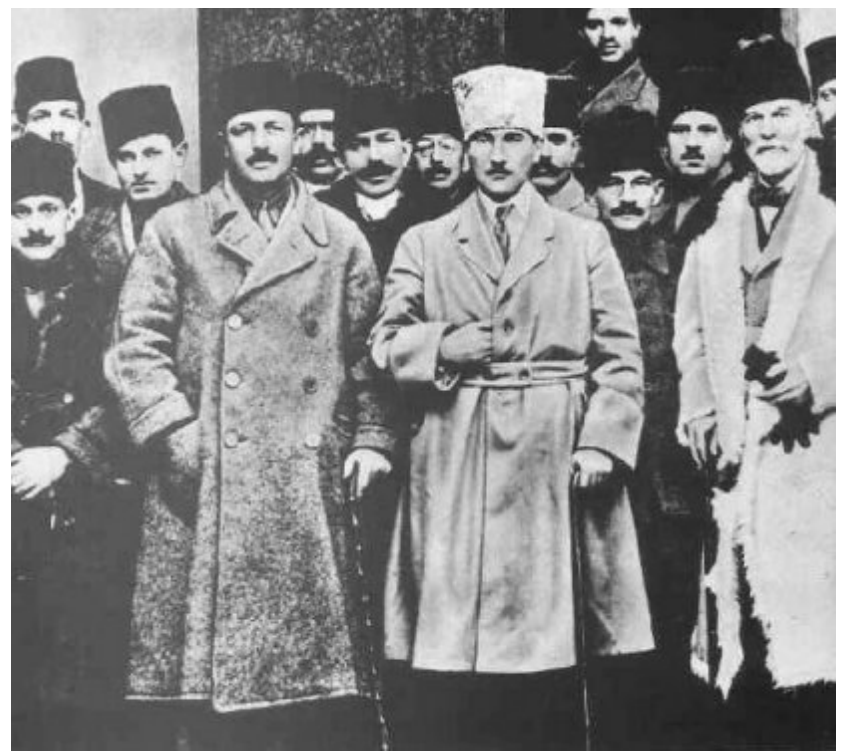

Ahmed Rüstem Bey Heyet-i Temsiliye ile Birlikte Ankara'da Mustafa Kemal Paşa'nın Yanında (Sağdan Birinci)

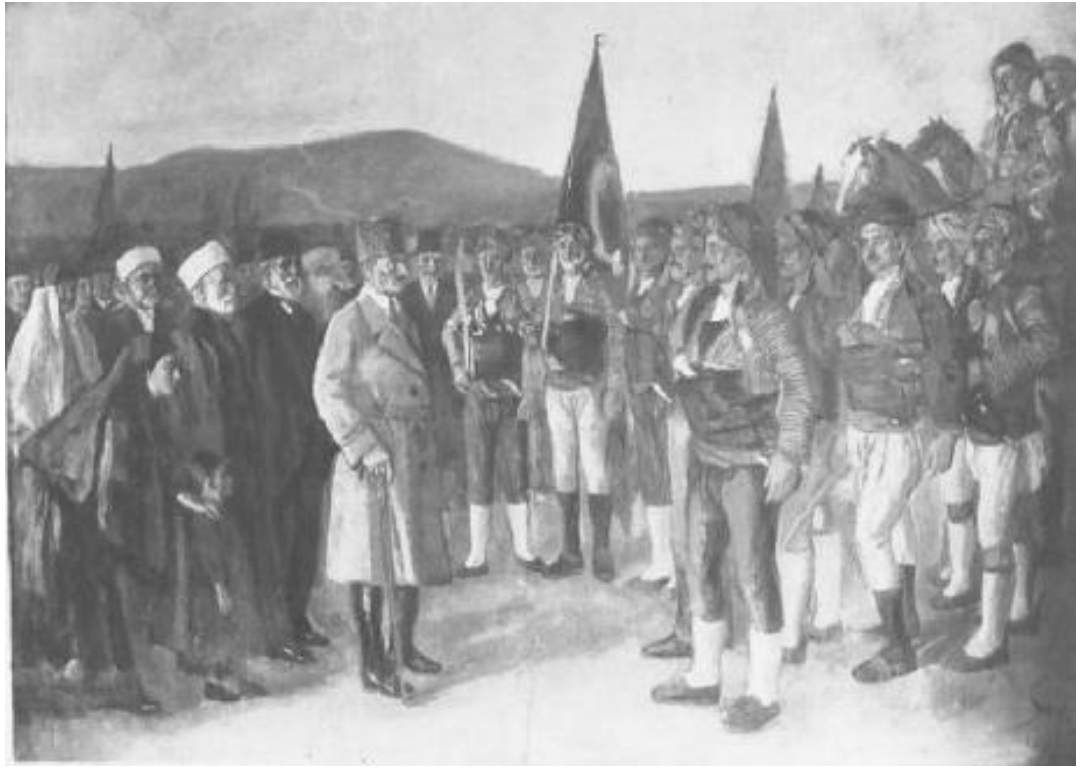

Mustafa Kemal Paşa'nın Ankara’ya Gelişi 


\title{
AHMED RUSTEM BEY
}

CI-DEYANT AMBASSADEUR DE TURQUIE A WASHINGTON

\section{LA GUERRE MONDIALE}

\author{
$E T$ \\ LA QUESTION \\ TURCO-ARMÉNIENNE
}

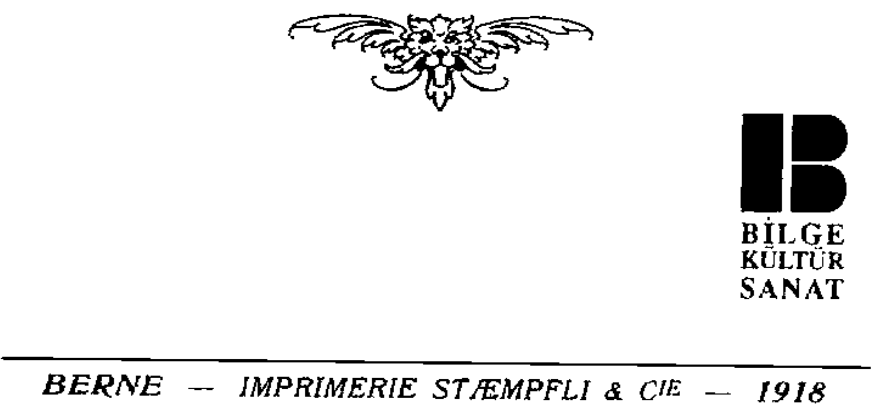

Ahmed Rüstem Bey, “La Guerre Mondiale La Question Turco-Arménienne (1918, Berne)"

(Cihan Harbi ve Türk-Ermeni Meselesi) 


\section{Ëhe Now ปूork Ẽimes}

APRIL 24, 1901

PORTE ANGRY WITH DIPLOMAT.

A. Rustem Bey, Who Was Charge at Washington, Accused of Treason. '.

LONDON, April .23.-Alfred Rustem Bey, who was First Secretary of the Turkish Legation at Washington in 1899, and later Charge d'Affaires in the absegce of Minister Ali Ferrouh Bey, has, according to a dispatch from. Constantinople, been summoned to that city to stand trial on the charge of treason in writing revolutionary articles for The Daily Mail of London, in which city he now resides. Hie sald today

I have heard of the treason charges. They are the result of a long-standing controversy between the-Government and myself. I have long urged the Government to abandion the suicidal. course it is now pursuing. Disaster must follow the Sulpursuing poilcy. When Charge d'Affaires at Washington, I had no superior between myself and Constantinople, and I used the opportunity to remonstrate with the Porte. first mildiy and then in vigorous terms. I had personal wrongs also for which I could get no redress. Treason in Turkey congists of opposition to the -Sultan's disastrous policy. Consequently I am charged with treason.

As I have not the silghtest intention of returning to. Constantinople, the -order for my arrest is a matter of: indifference to me I am not Identified with the Young Turk Party, but ' I; am - fuil: of sympathy with them or any programme for real Turkish reform.". ". 


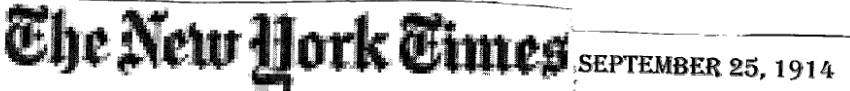
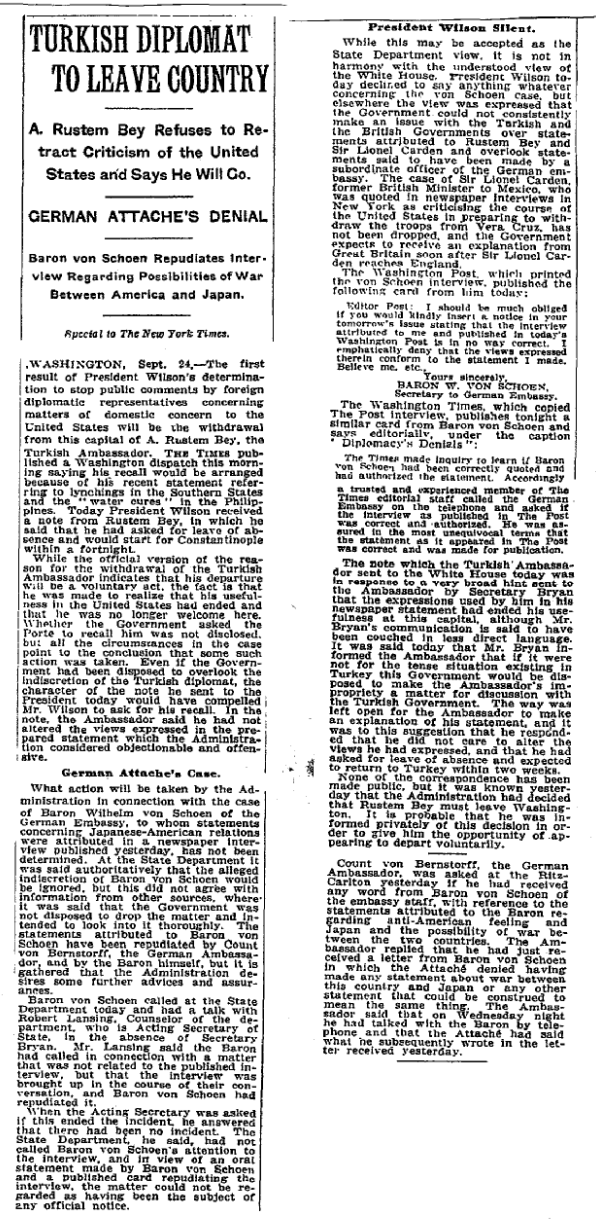

The New York Times, 25 Eylül 1914 


\section{Ehbe New Hork Ëimes max 15,1920}

\section{Kemal Condemned to Death; Two Other Turks Sentenced}

LONDON, May 14. - Mustapha Kemal, leader of Turkish Natlonalist torces in Asia Minor, was condemned to death at an extraordinary court-martial held in Constantinople on Wednesday, accordtng to a dispatch from the Turkish capital to the Exchange Telegraph Company. As he did not appear for trial he was found guilty by de: fault.

Others sentenced were Ali Fuad Fasha, former commander of the Twentieth Turkish Army Corps, and Alfred Rustem Bey, former Turkish Ambassador to the United States. 


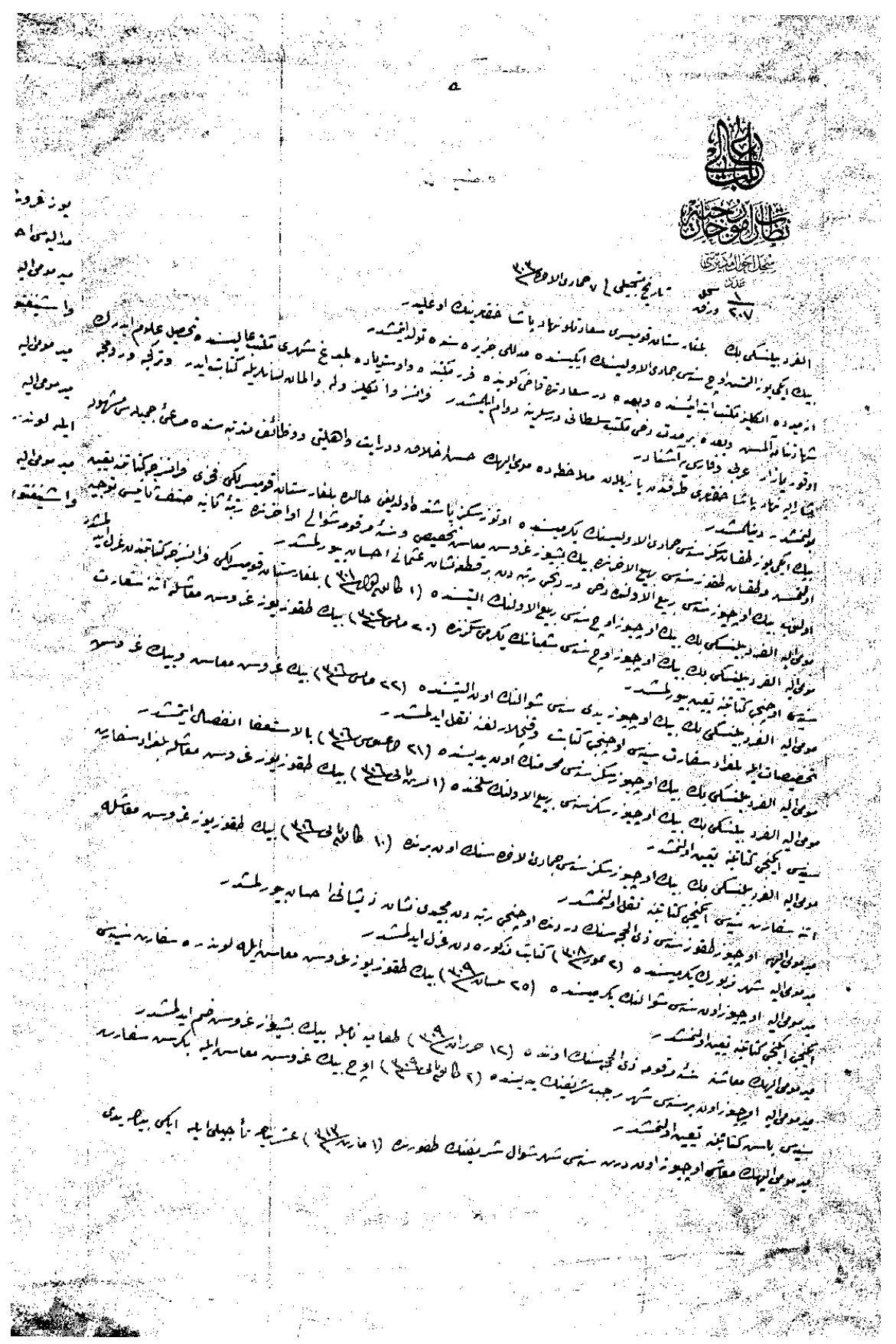

BOA, Y.PRK.HR.,Dosya No: 32, Gömlek No: 79,1320.Z.25 


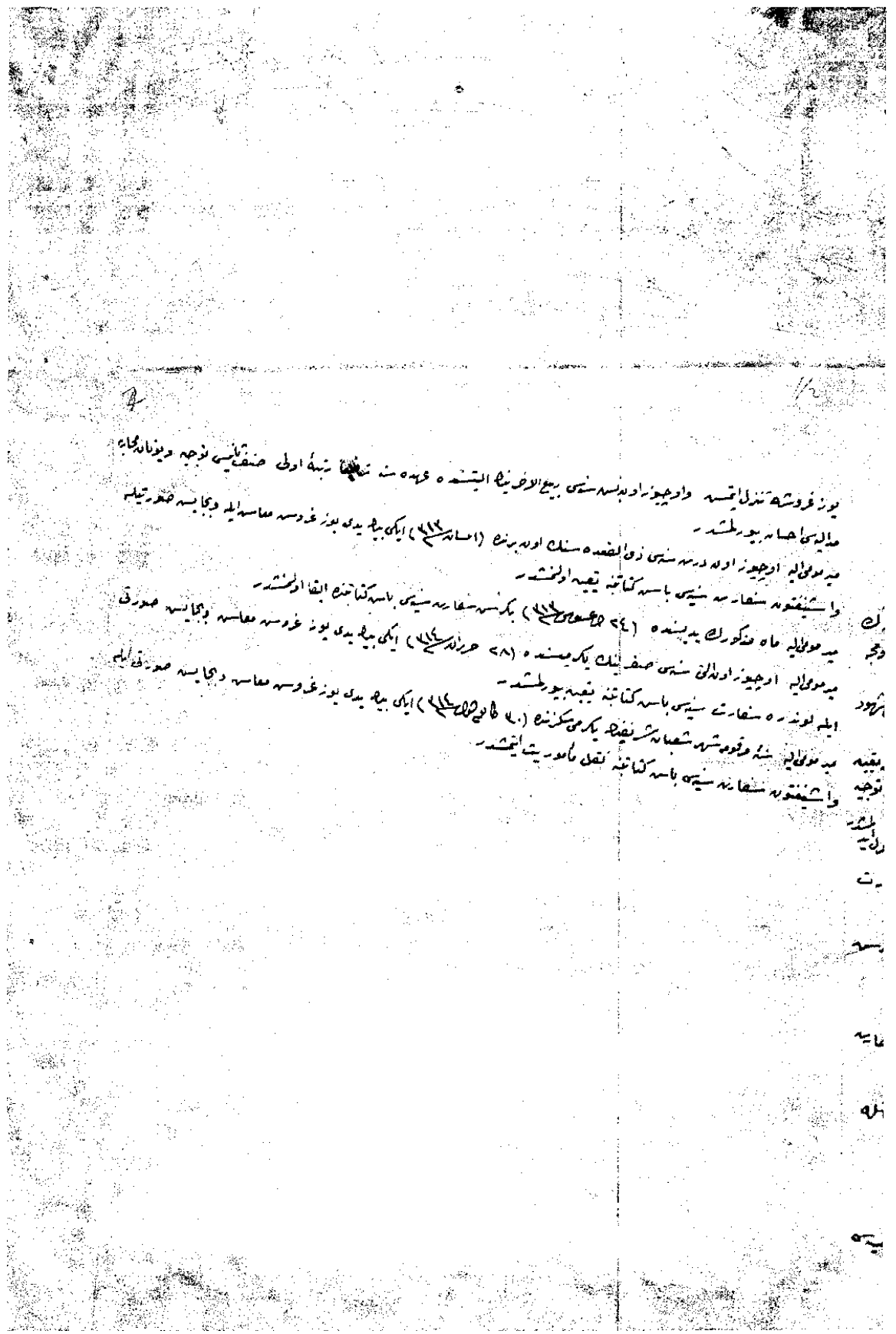

BOA, Y.PRK.HR.,Dosya No: 32, Gömlek No: 79,1320.Z.25 


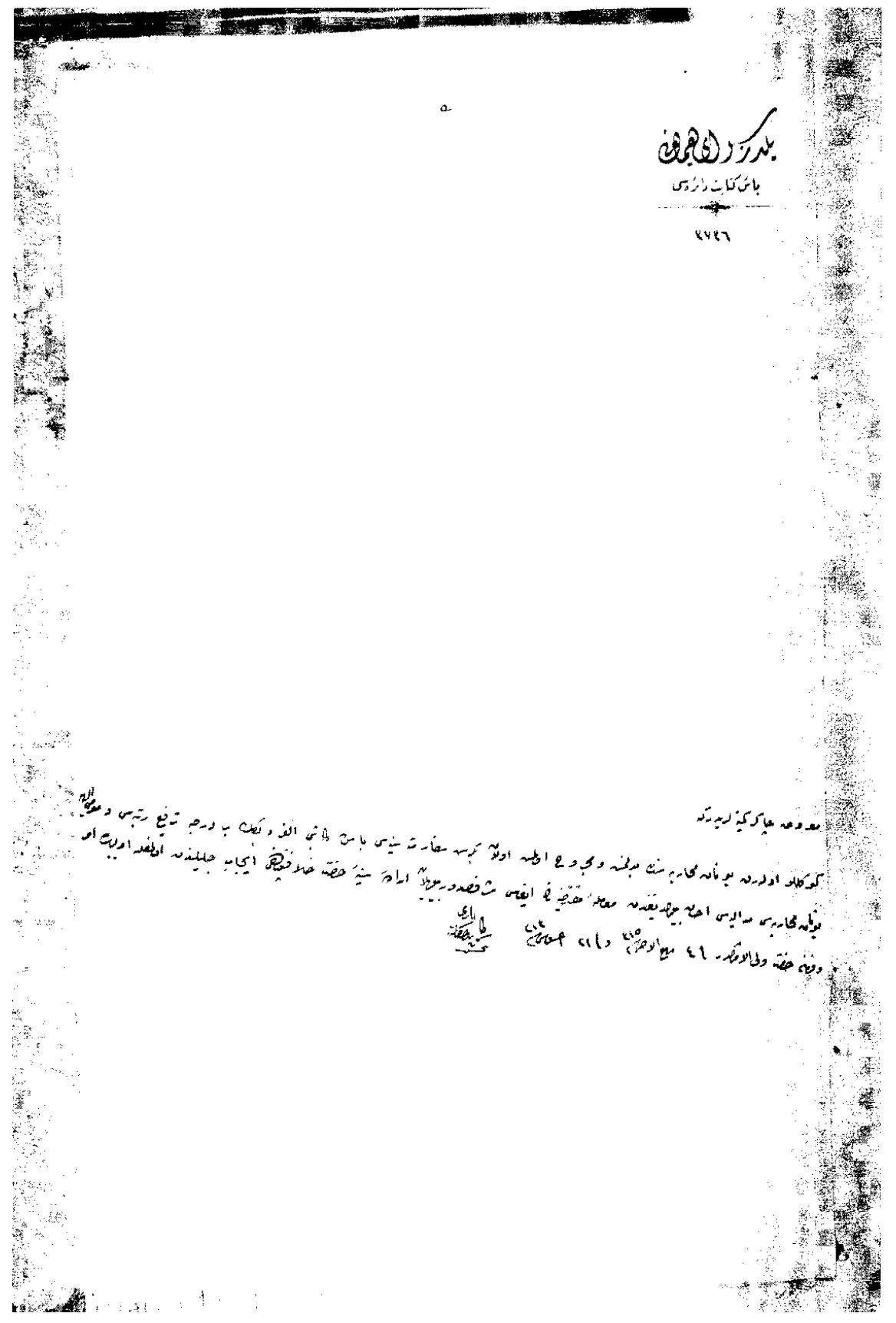

BOA, İ.TAL, Dosya No:120, Gömlek No:1315/R-263, 1315.R.4. 


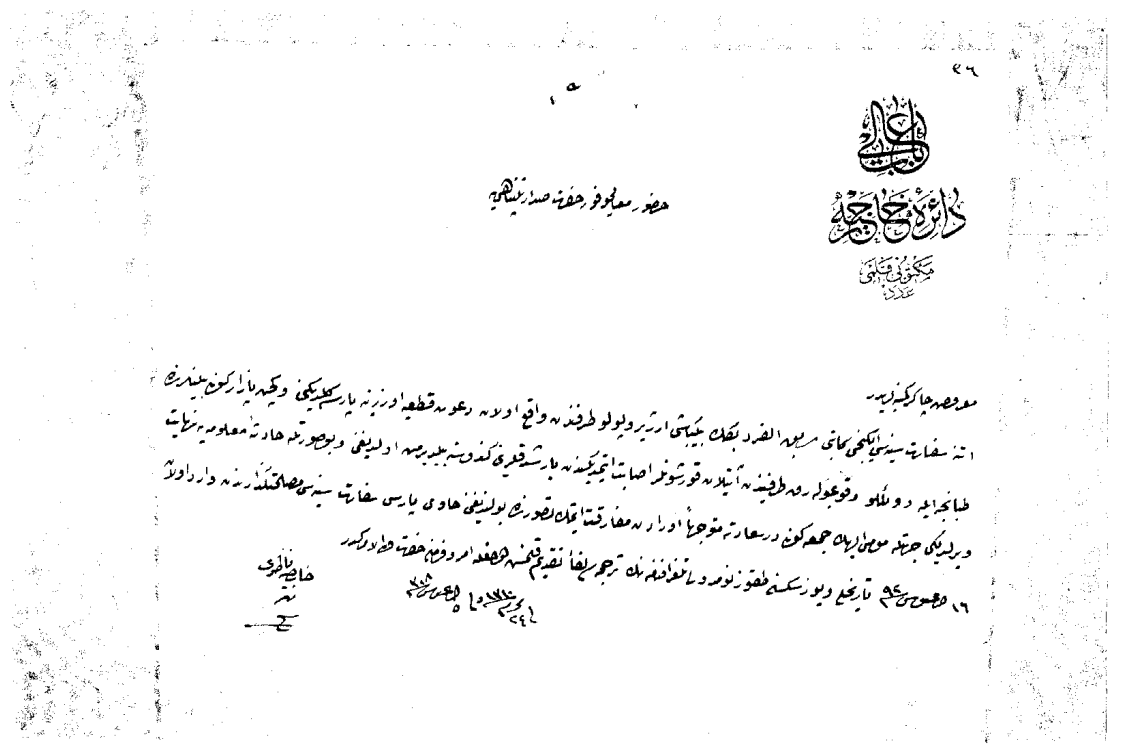

BOA, Y.PRK.A., Dosya No:7, Gömlek No:91, 1310.M.24.

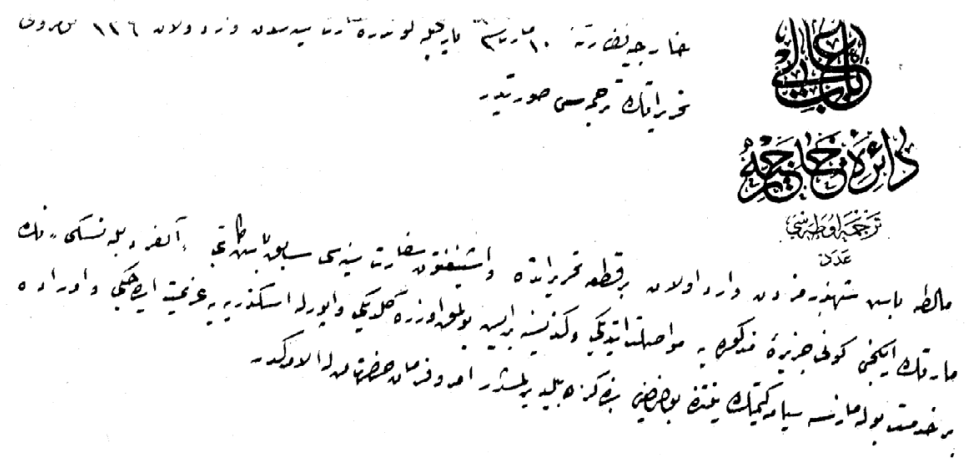

BOA, Y.PRK.HR., Dosya No:32, Gömlek No:74, 1320.Z.25. 
OSMANLIDA ONURLU BİR DİPLOMAT VE MILLİ MÜCADELE’NIN... 283

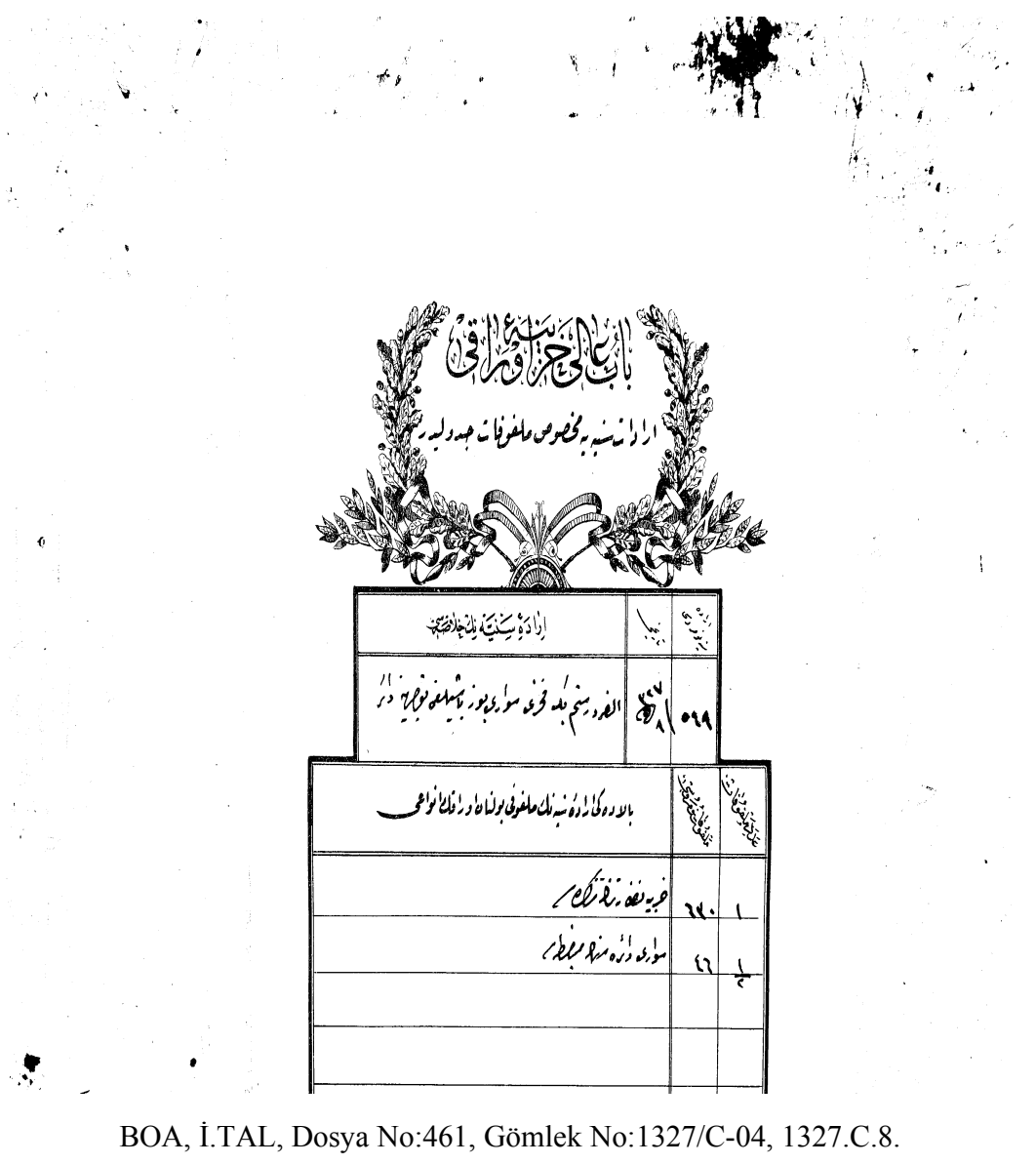




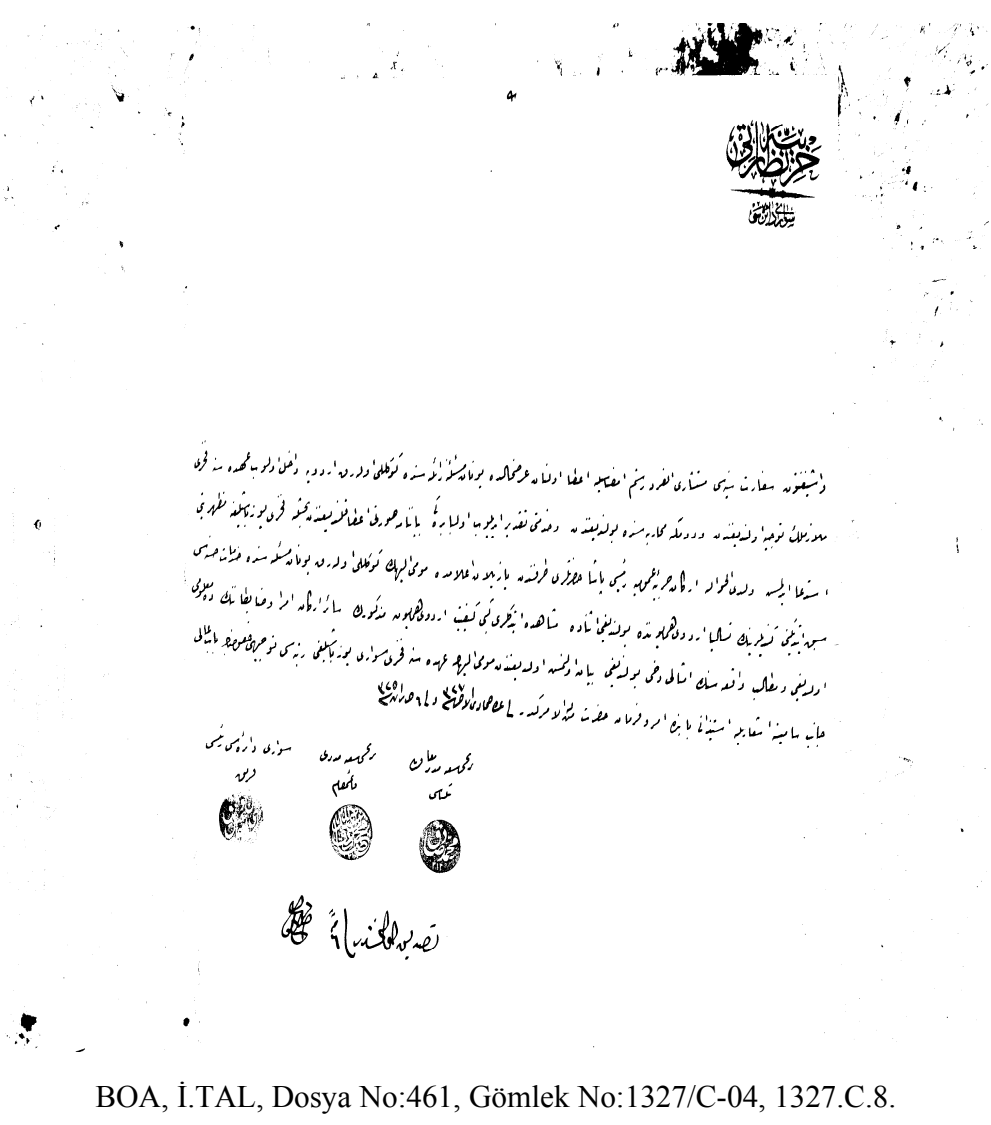




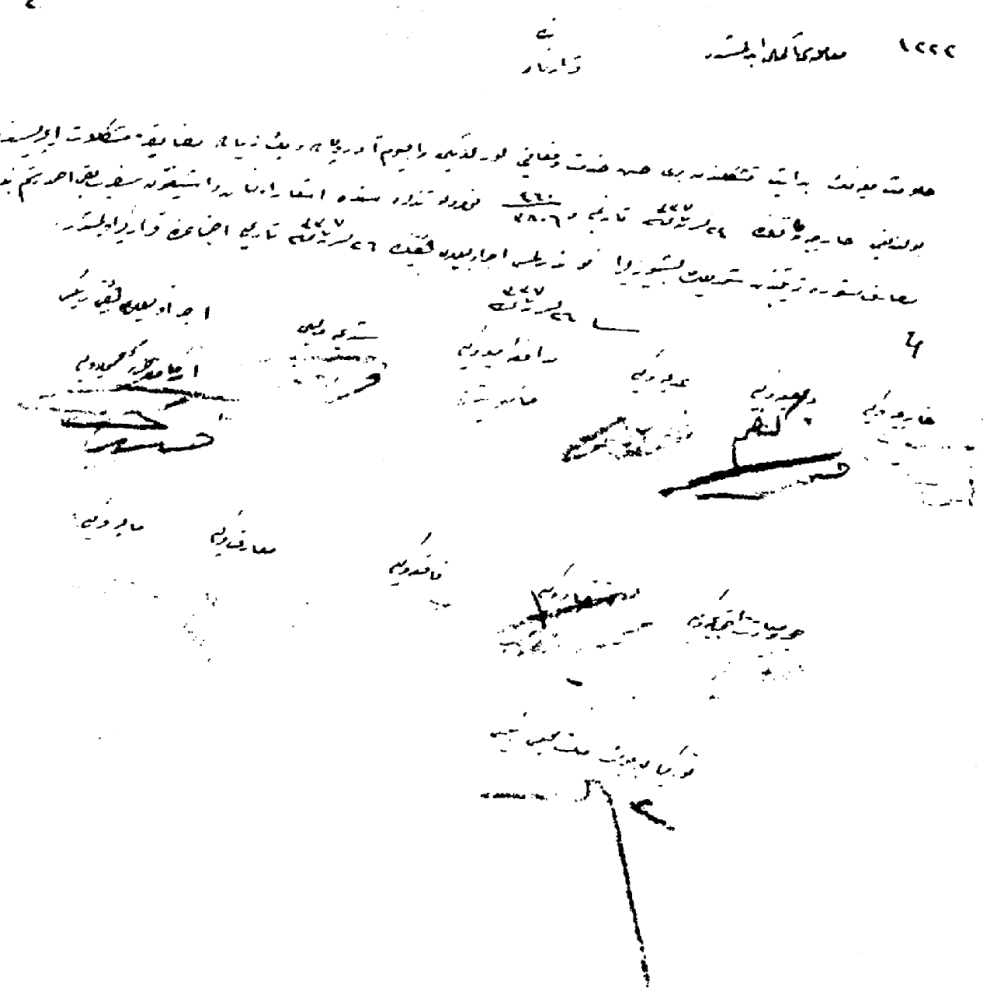

BCA, 030.18.1.1/4.39.2 
